\title{
Communicative solutions through technology: An evaluation of ESL textbooks in Brazil
}

\author{
Natalia de Souza Sterci
}

Follow this and additional works at: https://researchrepository.wvu.edu/etd

\section{Recommended Citation}

Sterci, Natalia de Souza, "Communicative solutions through technology: An evaluation of ESL textbooks in Brazil" (2016). Graduate Theses, Dissertations, and Problem Reports. 6723.

https://researchrepository.wvu.edu/etd/6723

This Thesis is protected by copyright and/or related rights. It has been brought to you by the The Research Repository @ WVU with permission from the rights-holder(s). You are free to use this Thesis in any way that is permitted by the copyright and related rights legislation that applies to your use. For other uses you must obtain permission from the rights-holder(s) directly, unless additional rights are indicated by a Creative Commons license in the record and/ or on the work itself. This Thesis has been accepted for inclusion in WVU Graduate Theses, Dissertations, and Problem Reports collection by an authorized administrator of The Research Repository @ WVU. For more information, please contact researchrepository@mail.wvu.edu. 


\author{
Natalia de Souza Sterci \\ Thesis submitted to the Eberly College of Arts and Sciences \\ at West Virginia University \\ in partial fulfillment of the requirements \\ for the degree of \\ Master of Arts \\ in \\ TESOL
}

Ahmed Fakhri, Ph.D., Chair

Cynthia Chalupa, Ph.D.

Susan Braidi, Ph.D.

World Languages, Literatures, and Linguistics

Morgantown, West Virginia

2016

Keywords: textbooks, technology, ESL

Copyright 2016 Natalia Sterci 


\section{Abstract \\ USING TECHNOLOGY TO IMPROVE ESL TEXBOOKS IN BRAZIL}

Textbooks are the main tools used by teachers and students in English as a Second Language/ English as a Foreign Language (ESL/EFL) teaching settings; Therefore, it is important to select the most appropriate textbook that meets both teachers' and students' needs. This study examines three textbooks commonly used in Brazilian private schools: New Interchange (Richards, 2000), American Headway 1 (Soars \& Soars, 2001), and Top Notch 1 (Saslow \& Ascher, 2006), all of which are published by non-Brazilian companies, to see how well they address the urgent need for communication-based EFL textbooks in Brazil. The current study seeks to help teachers in that country become aware of the merits and weaknesses of a variety of different textbooks and choose the most appropriate one for their curricula.

The evaluation checklist, which was designed to assess the efficacy of the textbooks in this study, was organized around two research questions: 1) Do the selected textbooks provide culturally authentic and meaningful content and promote the development of communication skills through a variety of activities? and 2) What type of technology can be adopted to address weaknesses in the textbooks with regard to communicative activities? The three ESL textbooks chosen for this study were analyzed unit by unit, in a systematic fashion, using the evaluative checklist selected.

The analysis of textbooks revealed that all had some shortcomings, such as a limited number of pre-reading, pre-listening, and topic preview activities and the lack of communicative tasks whereby students must negotiate for meaning. Suggestions for improving these weaknesses 
through the use of three technologies (Powtoon, WhatsApp, and WikiSpaces) are presented and evaluated. 


\section{Dedication}

I dedicate this achievement to my former, current, and future students who constantly remind me why I love my job so much. It is not about teaching, but learning. 


\section{Acknowledgments}

I am pleased to thank our Heavenly Father, my family, and friends for their love and support during the completion of this project. Primarily, I would like to thank the committee members, Dr. Ahmed Fakhri, Dr. Cynthia Chalupa, and Dr. Susan Braidi, whose guidance, corrections, and expertise made this thesis possible. I truly appreciate your feedback and your assistance.

Thanks to Dr. Angel Tuninetti, Chair of the World Languages, Literatures, and Linguistics Department, Sandra Dixon, and Stacy S. Fint, the Intensive English Program Director, for granting me the opportunity to teach. Especially, I would like to express my gratitude to Dr. Sandra Stjepanovic, Graduate Programs Coordinator, for her thoughtfulness, kindness, and encouragement.

I profoundly appreciate the help and the understanding of Lee Golden Wells. I also thank William and Brenda Wells as well as the bulldogs for providing me enjoyable and restful moments when I needed them the most.

I also express my deepest appreciation for the unconditional help of my friends Pri, Carol, Evelyn, Taisa, Olga, Rita, Zico, and Memo. I thank Jean Dailey and Lee Golden Wells who helped me improve the language and style of the thesis.

I conclude my acknowledgements with a heartfelt thanks to my mom, my father, and my beloved grandmother, who never ceased to support me in this endeavor. I also thank Eric and Marina Spears. At last, but not least, I thank my family. 


\section{Table of Contents}

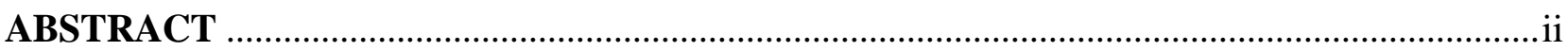

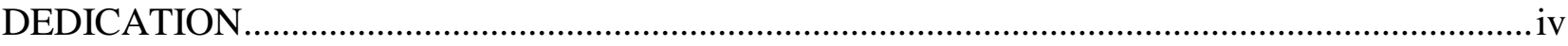

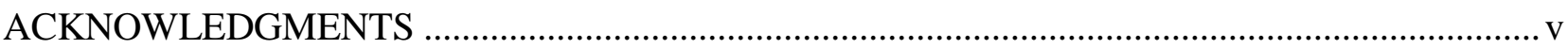

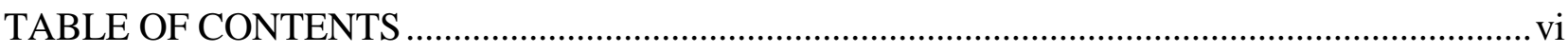

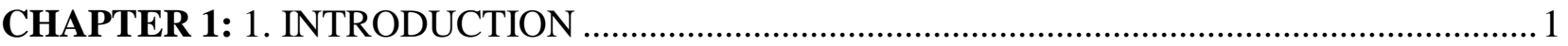

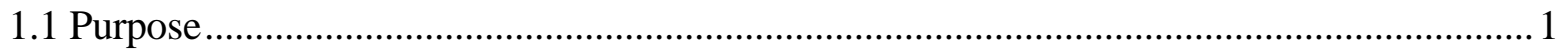

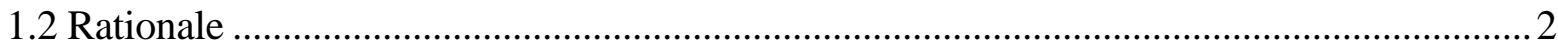

1.3 Teaching and Learning English as a Foreign Language in Brazil ................................... 4

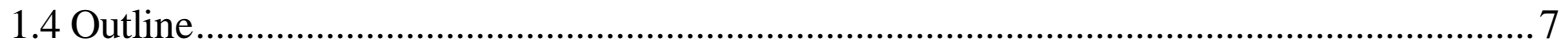

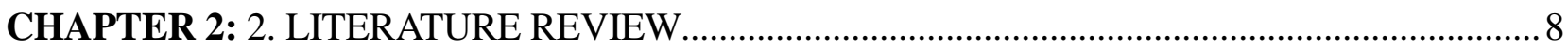

2.1 The Role of Textbooks in Teaching ESL/EFL ............................................................. 8

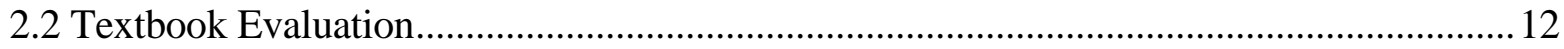

2.2.1 The Importance of Textbook Evaluation .................................................................... 12

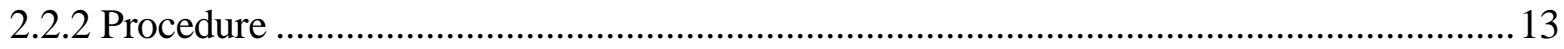

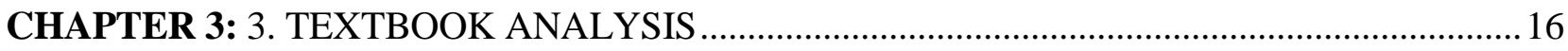

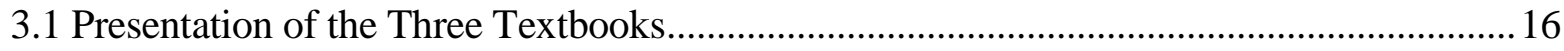

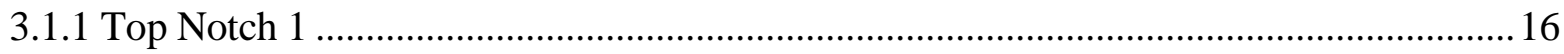

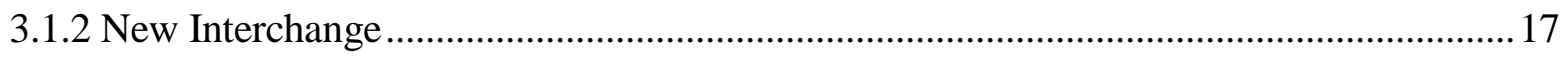

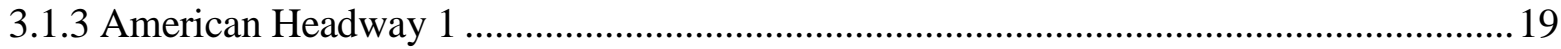

3.2 Analytical Procedure ….......................................................................................... 20

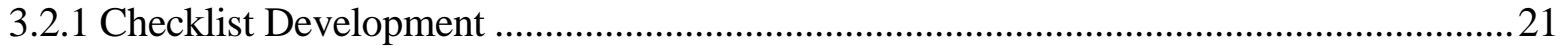

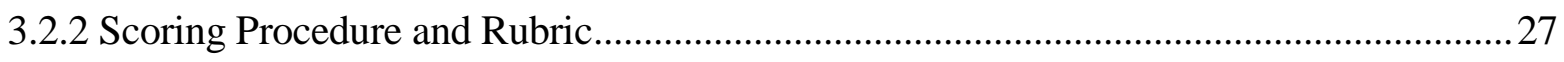

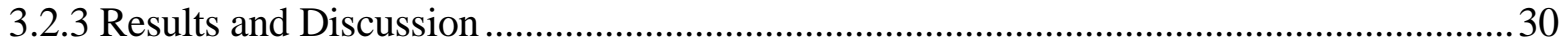


CHAPTER 4: 4. SUGGESTIONS FOR IMPROVING WEAKNESSES IN TEXTOOKS:

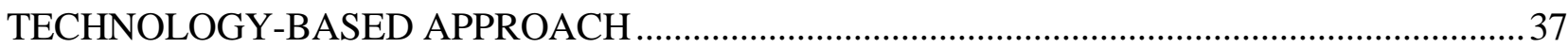

4.1 The Potential of Technology to Enhance Textbooks’ Weaknesses ..........................................37

4.2 Addressing Textbook Shortcomings Using Technology.......................................................... 39

4.3 Technology-Based Communicative Activities ......................................................................... 44

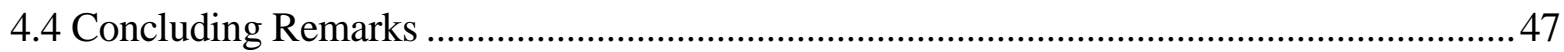

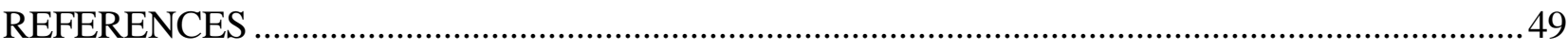




\section{CHAPTER 1}

\section{INTRODUCTION}

This chapter presents the purpose and rationale of the study and provides background information about the status of English in Brazil and the role of textbooks in EFL classes.

\subsection{Purpose}

This study examines three textbooks commonly used in Brazilian private schools published by non-Brazilian companies to see how well they solve the problem of the scarcity of communicative EFL textbooks in Brazil. The textbooks selected are Top Notch 1 (Saslow \& Ascher, 2006), New Interchange (Richards, 2000), and American Headway 1 (Soars \& Soars, 2001). A few studies have investigated the use of textbooks in public schools in Brazil (Miccoli, 2008; Santos, 1997), but it seems that, to date, there have been no studies regarding the textbooks used in private schools, which is especially problematic because students in private schools assume that the instruction fits their needs better than that in the public schools. Specifically, the study addresses two main questions:

1) Do the selected textbooks provide culturally authentic and meaningful content and promote the development of communication skills through a variety of activities?

2) What type of technology can be adopted to address weaknesses in the textbooks with regard to communicative activities?

The significance of this study is threefold. First, this study will highlight the importance of evaluating textbooks. Textbook evaluation is believed to be valuable because it can help the evaluator to identify the weaknesses of the textbooks. Second, once these weaknesses are identified, educators and publishers can correct or supplement them. Finally, this study will suggest technology-based measures to compensate for the weaknesses that were found in the textbooks. The integration of technology in EFL classes can also motivate students. In fact, 
technology has also proven its great value in engaging learners who want to improve their English. Al-Jarf (2004) suggests that the use of technology enhances English learning by encouraging them and giving them a sense of accomplishment.

\subsection{Rationale}

EFL teachers spend a considerable amount of time selecting a textbook; therefore, it is understandable that selecting the most appropriate one is critical. Teachers use textbooks as the main tool in teaching a foreign language. Sheldon (1988) states that textbooks are considered to be "the route map" of an effective and well-structured English course (p. 238). This is particularly true in the EFL setting, including Brazil where English schools rely on EFL textbooks to teach English. Byrd (2001) argues that when teachers are not fluent English speakers, which is the case of many teachers in Brazil, adopting an English textbook is essential. According to McGrath (2002), using a textbook also provides a sense of security to the instructor, as well as methodological guidance to prepare the classes. For this reason, Sheldon (1988) recommends that teachers evaluate textbooks because these evaluations benefit teachers and the institution in the process of choosing the best material and make them aware of the merits and weaknesses of the textbook. Furthermore, textbook evaluation is necessary because teachers depend extensively on textbooks to provide content. These points will be further discussed in Chapter 2.

The textbooks evaluated here are intended for English as a Second Language (ESL) audiences, meaning English language learners living in English-speaking countries. This is in contrast to EFL, which refers to English language learners outside the Anglophone world. Even though EFL and ESL audiences have different needs, this thesis will use the term EFL to refer to the English-language students in Brazil because the textbooks under consideration are used in an EFL setting. However, some of the cited literature was written in reference to the ESL setting. 
The textbooks selected for this study are perceived to be better in the EFL field because they have integrated technology and offer some communicative tasks. Particularly, Top Notch 1 has been considered by teachers to be good at providing communicative tasks and integrating technology meaningfully. However, there is the need for a direct and systematic evaluation to determine in a reliable fashion if the textbooks actually fulfill these needs. In fact, it will be shown later (in Chapter 4) that the textbooks include a large number of units without tasks that support communicative language teaching (CLT) and that they could be enhanced by the use of technology. ${ }^{1}$

The study recommends a number of technologies to improve the textbooks because, once purposefully integrated, the use of technology in EFL classes can bring a wide number of advantages to the students. Foremost, it can enhance communicative language teaching. Undeniably, technology has become a regular part of students' lives, both inside and outside of the classroom. Learners use technology for enjoyment and for information gathering. Learners also use technology as a tool to enhance the learning process (Croop, 2011). Easy access to the Internet, for instance, provides teachers and learners with tremendous search capability enabling access to contemporary information about any possible topic (Mill, 2000), which explains its popularity among teachers and learners. Furthermore, technology has the potential to motivate students by maintaining their interest and by making learning fun; however, it must be integrated in a pedagogically sound way in order to maximize its benefit. Bennett and Berson (2007) affirm

\footnotetext{
${ }^{1}$ Richards and Schmidt (2002) indicate that Communicative Language Teaching (CLT) emphasizes the teaching of the four skills (listening, speaking, reading, and writing). Both taskand-content-based activities are also utilized in order to expose learners to authentic target language situations that can be encountered easily in real life (for example, scheduling a doctor's appointment on the phone). The main goal of this language theory is to achieve communicative competence, defined by Hymes (1972) as the understanding of both grammar and language use applicable in a given context. Language must be used properly in different social contexts and for interaction and communication.
} 
that when used purposefully, educational websites can be highly beneficial to students’ learning abilities. Chen (2004) and Kong (2009) claim that websites contribute positively to learners’ motivation, and their performances can improve considerably. For this reason, EFL classes should integrate online materials with textbooks. The benefits of technology to teach EFL will be further discussed in Chapter 4.

\subsection{Teaching and Learning English as a Foreign Language in Brazil}

Globalization has helped spread the use of English throughout the world, increasing the demand to communicate using this language and establishing the role of English as a global lingua franca. Brazil is a country that is experiencing economic growth; therefore, the ability to demonstrate proficiency in English plays an increasingly important role in Brazilian society.

Based on the need for proficiency in English, Brazilians have been looking for quality English-language education. Santos (2002) points out that "English is by far the most widely taught foreign language in Brazil” (p. 28). English language learning is mandatory for students beyond middle school, which has led to the necessity of making the language more accessible to younger speakers. Offering more evidence on the importance of the language in the country, De Mejia (2002) affirms that being proficient in English in Brazil nowadays is a basic requirement and results in better job opportunities, higher chances of attending a distinguished university, and better chances of being socially privileged. As a result of the high demand for people who can speak English fluently, many private English schools have prospered in Brazil. In fact, De Mejia (2002) claims that the number of private English institutes has been increasing rapidly, and in 2001, Brazil had more than forty-five English schools spread over the country with more than 4,500 affiliates. The British Council (2014) suggests that about 2.5 million people are currently studying English at private schools in Brazil. 
Although English is taught for six years in public schools, most students who become proficient in English do so at private institutions. The failure of Brazilian public schools to build solid English-language programs has to do with Brazil’s recent history and with poor teacher qualifications. Bohn (2003) explains that many reforms were implemented in the educational system of the country. From 1971 to 1991, teaching a foreign language in Brazil was practically banned in public schools. The result of this action was the emergence of private language schools. Bohn (2003) also claims that the lack of good teaching practices and methods in Brazil's public schools is a burden to English language educators in Brazil. The reality is that because of the country’s scarcity of teachers who are acquainted with teaching approaches and methodologies, public classrooms provide less than optimal instruction. The lack of instruction focusing on communication and negotiation of meaning is one of the reasons that Brazilians educated only in public schools cannot communicate efficiently in English. Leffa (1999) has argued that teachers consider a focus on reading as the cause of the lack of proficiency and the limited ability to speak English among students. This makes sense given that the language setting focuses extensively on texts and translations.

As researchers have noted, Brazil has not yet successfully implemented communicative pedagogy (Oliveira, 2008; Da Silva, 2012) in its public schools, which lies at the heart of the problem. Bohn (2003) claims that English classes in public schools of Brazil today use such outdated methods that they are “archeological” (p. 169). As a result, English language learners attend private English schools because they consider them to provide more reliable instruction, especially since these schools develop their own materials or use imported textbooks that claim to provide more communicative and meaningful language teaching practices.

Language textbooks in Brazil are necessary for teachers to build the pedagogical framework for their language classes. Santos (2002) notes that when public institutions decide to 
use textbooks, they frequently choose the ones written by local publishers. Although these textbooks and their teaching methodologies emphasize written rather than oral skills, they are reasonably priced and can be easily distributed.

To further analyze the demand for English proficiency in Brazil, the British Council (2014) interviewed individuals who either were currently taking English courses or intended to do so within a year. Nine out of ten participants studied English when they attended school. The ones currently studying in private institutions expressed concerns with the teaching methods and the quality of the materials of their current courses. Surprisingly, when learners were asked what item was mandatory to engage them in a course, textbooks were acknowledged as the most important factor. Four out of ten students claimed that they would take a course if the material was appealing. The interviewed individuals admitted that the poor quality of teaching material would cause them to withdraw from the course. Students seek well-developed material. Learners also look for tasks that can easily be applied to their reality. In addition, they favor textbooks that are visually attractive and contain both contextualized and relevant information. As previously stated, Brazil values competent English speakers. Because learners value the quality of the textbooks that will help them to become English proficient, it is vital to offer learners the best material. Therefore, textbook evaluation is particularly important in the Brazilian setting. To ensure the efficiency of a textbook, a pre- and a post-evaluation can be conducted, which justifies the importance of textbooks and evaluating them accurately.

Because the textbooks used in public schools are so ineffective, private institutions in Brazil adopt well-known foreign textbooks. Language schools are the default option for learning English, as 87\% of those surveyed by the British Council (2014) stated that private schools are their best alternative for becoming proficient speakers of the language. Only $6 \%$ of the interviewees would hire a private teacher, while 3\% would attend courses at companies, and 2\% 
pointed to language study centers as the best alternative. Finally, $1 \%$ of the individuals affirmed that they would prefer to learn English through an online course, and the remaining 1\% would learn the language with the guidance of textbooks or similar material.

\subsection{Outline}

The present study seeks to answer some of the questions regarding the efficacy of English textbooks through a thorough evaluation and analysis of the books' shortcomings. It is organized into four chapters. This first chapter outlines the purpose of this study and explains the status of EFL textbooks in Brazil. It not only discusses the importance of evaluating EFL textbooks, but also describes how technology can improve them. Chapter 2 is a review of the literature on ESL textbook evaluation and describes the role of textbooks in teaching ESL, the importance of textbook evaluation, and the procedures to design a checklist. Chapter 3 describes the three textbooks, the procedure used to evaluate the textbooks, and the results of the analysis, highlighting the weaknesses of the three textbooks. Additional information about the checklist developed in this study is also provided. Finally, Chapter 4 proposes ways of improving weaknesses in textbooks using technology-based measures. The final chapter summarizes the findings and suggests topics for further research. 


\section{CHAPTER 2}

\section{LITERATURE REVIEW}

The purpose of this chapter is to review the literature on textbook evaluation and discuss both the role of textbooks in teaching ESL/EFL and the importance of textbook evaluation.

\subsection{The Role of Textbooks in Teaching ESL/EFL}

Textbooks are considered extremely important for teaching and learning EFL. Roberts (1996), Coracini (2011), and Rahimpour and Hashemi (2011) claim that English Language Teaching (ELT) is a discipline that depends on a textbook to construct language practice, learning theory, and course content. Cunninsworth (1995, p.67) states that textbooks are "an effective resource for self-directed learning, an effective resource for presenting materials by the teachers, a reference source for students, a syllabus that reflects pre-determined learning objectives, and support for less experienced teachers who have yet to gain in confidence.”

Ellis (1997) has also argued that textbooks are mandatory in an EFL class, and Santos (2002) suggests that English textbooks can help learners by providing a guided structure through which they can associate the learning outcomes with certain units and themes. In addition, Coracini (2011) affirms that textbook activities aid teachers and students in accomplishing their communicative goals. Moreover, Khodabakhshi (2014) argues that textbooks are even more useful if they address particular purposes, “needs, interests, ages, and characteristics of specific groups of learners” (p. 960), and if they incorporate authentic tasks that increase students' interest in the learning process. The aforementioned arguments support Ansary and Babaii’s (2002) description of textbooks as “valid, useful, and labor-saving tools” (p. 2). Because textbooks combine a variety of materials in a condensed and efficient manner, it is understandable why teachers rely considerably on them in their teaching. 
Textbooks are the main tools used by teachers and students in ESL/EFL teaching settings. Riazi (2003) asserts that textbooks have a fundamental role for both language teachers and learners. Textbooks are the most prevalent factor in the foreign language setting after the instructor. They are adopted to a large extent due to the various benefits that they offer. Ur (1996) argues that textbooks provide a structure to be followed and positively contribute to a sense of security for both teachers and students. Another important advantage indicated by Ur (1996) is that textbooks contribute to a sense of autonomy for learners by stating that "the learner can use the coursebook to learn new material, review and monitor progress with some degree of autonomy. A learner without a coursebook is more teacher dependent” (p. 184). Learning independently is important because when students know what subject is going to be discussed next in their textbook, they feel less pressured because they can predict what content will be taught next. Also, textbooks facilitate class interaction, class time management, and language learning with adequate texts and learning tasks developed for the target audience. They save time for the teacher who would have to prepare the activities when a textbook had no interactive tasks already prepared. To Guerrettaz and Johnston (2013), teachers perceive textbooks positively because they "provide structure and content for learning activities, to organize curriculum, and to frame classroom ideologies, among many other roles” (p. 781). Such roles can certainly ease the burden on teachers, considering that they have other tasks to worry about — including grading and adapting instruction to fit students' needs. All of these factors explain why textbooks are seen as indispensable.

Previous research has also examined the teachers' opinions about the role of textbooks and their importance. In a study in secondary schools in Hong Kong, McGrath (2006) found that some teachers do not perceive textbooks to be as important as do their students. Learners showed a stronger attachment to their textbooks, whereas teachers used both their textbooks and their own 
material. In contrast to their students, instructors cited positive and negative aspects related to their textbooks. Other research shows that teachers’ opinions regarding the importance of textbooks are highly influenced by the teaching context (Richards, 1998; Richards \& Mahoney, 1996) and the level of experience of the teachers (Gray, 2010). For instance, Lee and Bathmaker (2007) indicated that English teachers in a vocational school in Singapore did not perceive textbooks as important. After downloading the textbooks they were meant to use, instructors often substituted them with testing worksheets with similar questions to the ones students would find in the test that evaluates the educational system of the school. Thus, teachers tried to supplement textbooks' shortcomings because they were concerned with the examination system. They were also not sure how well the students would perform.

Similarly, Chandran (2003) cites the opinions of English lecturers in a Malaysian high school about integrated textbooks that focused on the communicative approach. Lecturers showed a preference for commercial and easily accessible textbooks. These types of materials were used to supplement the textbooks in order to expose learners to relevant content for exams. In brief, according to McDonough and Shaw (1993), to use a textbook in the EFL teaching setting effectively, teachers must use additional teaching materials.. Surely, when a textbook is evaluated after its use, more adequate supplementary material may be designed.

Teachers, nonetheless, still value textbooks because of their practical nature. Textbooks lessen the burden of class preparation, are time-saving, and ease the process of teaching and learning considerably. Textbooks also offer methodological guidance (McGrath 2002; Tomlinson and Masuhara, 2010). Because finding interesting texts and preparing classes is time-consuming, it makes sense that teachers value these roles of textbooks.

It could be argued that the role of the textbook may be limited, since learners have different needs that cannot be provided by a single book. Ur (1996) mentions possible drawbacks: (1) some 
topics may not be relevant or interesting to a given group of learners, especially because of their mixed backgrounds; (2) books can restrict teachers' resourcefulness, creativity, and independence; (3) homogenous books may not suit the different levels of knowledge, ability, and learning preferences and strategies of a specific group; and (4) finally, a lack of creative and interactive tasks that are not provided by the textbook may discourage students and undermine the teacher's initiatives. As an example of a topic that may not be relevant for a specific group, questions about a first date can be found in many textbooks. Inquiring if the practice of dating is popular in the students' countries implies that this practice is common in every country, which is not the case. In addition, Carrell and Korwitz (1994) point out the large number of gender biases displayed by many ESL books. For example, Ghorbani (2009) found that males appeared first in 92\% of mixed gender word pairs (he and she, for instance) in the ESL textbook Person to Person (1995). This example shows what may be a sexist bias.

Although the use of textbooks may reduce teacher resourcefulness and creativity because it reduces the necessity of preparing activities, a considerably large number of renowned educators agree that no book will ever be perfect (McDonough \& Shaw, 1993; Sheldon, 1987; Skierso, 1991). Certainly, the benefits of using textbooks considerably outweigh these drawbacks because of the autonomy, security, and structure that they provide. For this reason, it will be unwise to abandon textbooks; instead they should be improved by evaluating their effectiveness and supplementing them with technology.

As mentioned in Chapter 1, in private schools in Brazil, the British Council (2014) found teaching materials to be the most important factor in keeping students committed to a course. Therefore, even if textbooks are not perceived in the same way around the world, they matter a great deal for the purposes of this study, which focuses specifically on the context of private institutions in Brazil. 


\subsection{Textbook Evaluation}

\subsubsection{The importance of textbook evaluation.}

For several good reasons, EFL textbooks should be evaluated. First, textbooks play an important role in teaching ESL/EFL. Second, according to Littlejohn (1998) and Ellis (1997), textbook evaluations can identify the positive and negative aspects of materials. Moreover, McGrath (2002) suggests that both teachers and learners can conduct textbook evaluation before or after using the material. This task can be conducted with little difficulty with the use of a questionnaire eliciting feedback from the students. Once this process is concluded, it is important to consider the findings and make sure that changes are made to benefit teachers and learners. To make the evaluation process easier, Cunningsworth (1995) recommends that evaluations be simple: "It is important to limit the number of criteria used, the number of questions asked, to manageable proportions, otherwise we risk being swamped in a sea of details” (p. 5).

The third reason why textbook evaluations are important is their usefulness in determining how suitable textbooks are for achieving the objectives of the curriculum. It is imperative that material developers indicate formally how curriculum specifications are accommodated (Johnson, 1989). Byrd (2001) acknowledges that the most important question in a textbook evaluation is "how the material fits into the curriculum" (p. 416). Tomlinson and Masuhara (2010) explain that to evaluate and supplement the textbooks' needs, the evaluator should consider the curriculum, the teacher, and the students' needs. It is important to consider how the textbook fits the curriculum in a context with a large number of EFL students. Byrd (2001, as cited by Tomlinson \& Masuhara, 2010) also states the following:

In order to meet the students' needs, the evaluator should have enough knowledge about the students to find whether there is a correspondence between the textbook (considering the main elements of content both linguistic and thematic, examples, exercises, or tasks, and the 
presentation and format) and the students. Similarly, the evaluation checklist enquires about the effectiveness of the main elements of the book (content, examples, tasks, and presentation or format) for the teachers who want to use it (p. 343).

Therefore, it is crucial that the evaluator knows how the textbook fits into the curriculum and meets the learners' needs. For this reason, questions regarding the content, the tasks, and the appearance of a textbook should be included.

In brief, the reasons to conduct textbook evaluation include the following: (1) books are the main resources used for teaching; (2) teachers can conduct pre- and post-use evaluations to identify textbooks' strengths and weaknesses; and (3) appropriate selection of textbooks can contribute to the achievement of an institution's goals and determine how the material fits into the curriculum.

Once the evaluation is conducted and the textbooks' strengths and weaknesses are identified, the evaluator will be able to address the textbooks' shortcomings by providing additional materials. The following subsection will address how textbook evaluation should be performed and how the use of checklists can help evaluators to complete this task successfully.

\subsubsection{Procedure}

Various procedures have been used to evaluate textbooks. The most common procedure is the use of checklists. Ellis (1997) argues that checklists are efficient because systematic evaluation provides reliable results. McGrath (2002) points out that checklists ensure that all pertinent items have been included in the evaluation.

Sheldon (1998) and Ur (1996) suggest that, ideally, evaluative checklists should include the layout, methodology, aims, organization, and the degree to which extent the textbook fits the curriculum and the learners' needs. Among these items, the authors recommended that checklists should evaluate important aspects such as 1) the educational and social approach, 2) the layout of the material, and 3) the effectiveness of supplement materials. It is also important to ensure that 
textbooks provide meaningful input and a diversity of topics. Another important factor is to offer contextualized input in tasks with authentic and real-world situations.

Some authors suggest that a good evaluation should consider the extent to which the textbook meets the students' needs. Nunan (1991) asserts that selecting textbooks can be considerably easier once the evaluator makes sure that the material and learner's goals and needs are lined up. The author also states that effective evaluation assures that the materials are compatible with the requirements and the ideology of the institution where they are being used. More recently, Rahimpour (2013) proposes additional criteria for textbook evaluation. The author indicates that cultural items, content, and linguistic features should fit learners’ personal characteristics, interests, needs, and background. It is important to consider the teachers' and institutions’ needs as well.

McDonough and Shaw (1993) proposed a condensed evaluative checklist with twenty-two questions. Their evaluative framework consists of a predictive and a retrospective evaluation. This framework is designed to identify textbooks' strengths and weaknesses and includes two stages: 1) an extrinsic analysis that evaluates the textbook by looking at external aspects, such as the cover or the table of content, and 2) a more precise evaluation of the intrinsic content, including the quality of the texts and the graphic features. This more succinct method of evaluation is efficient and manageable.

There is no general agreement about how extensive the checklists should be; however, both McGrath (2002) and Tomlinson (2003) emphasize the importance of including multiple pedagogical aims related to the curriculum in a self-developed checklist. Some authors believe that the creation of vast checklists helps evaluators to analyze books consistently. As an example of the use of extensive evaluative tools, Sheldon’s (1988) and Breen and Candlin’s (1987) checklists contain fifty-three and thirty-four questions respectively. Cunningsworth (1995) 
affirms that efficient evaluation occurs when useful questions are asked. Undoubtedly, it is fundamental to create checklists with meaningful questions. However, many authors defend the use of more compact checklists. Swales (1980) even claims that too many questions do not necessarily lead to conclusive evidence.

Sheldon (1988), however, defends the idea that teachers should evaluate textbooks using shorter checklists. The author argues that the evaluation should be conducted in a personalized way, adapting checklists whenever needed. Also in opposition to long checklists, Cunningsworth (1995, p. 5) suggests that any modifications are appropriate to accommodate the evaluator's needs when a checklist is being developed. Although there is no consensus regarding how extensive a checklist should be, it is important to aim for a manageable evaluation, which can be conducted with the aid of a concise checklist. In addition, reduced checklists are practical and easy to implement. Ellis (2014) and Tomlinson (2003, 2010, 2011) reinforce this practice and even propose a list with seven items to help create checklists to evaluate ESL textbooks.

Finally, Sheldon (1988) indicates that, because there is no consensus to be followed, evaluators should reduce the checklist and the scoring system to the items that are significant for their evaluation. For the purposes of the present study and based on the research questions, the literature review, and the textbook situation in Brazil, a more concise checklist with eight questions was developed. In the following chapter, the creation process and the justification for the selected questions used in this study are discussed in the analytical procedure that follows the presentation of the textbooks. 


\section{CHAPTER 3}

\section{TEXTBOOK ANALYSIS}

This chapter gives a general description of the three textbooks selected for the study, describes the analytical procedure, and discusses the results of the analysis.

\subsection{Presentation of the Three Textbooks}

\subsubsection{Top Notch 1}

Written by Joan and Allen Ascher and published in 2006 by Pearson-Longman, Top Notch 1 is the second textbook in a six-level ELT course for adolescents and adults. Top Notch 1 claims to prepare learners to communicate with both native and non-native speakers of English. One of the major features of Top Notch 1 is the focus on colloquial dialogues and a learner-centered methodology. The textbook contains communicative exercises that require learners to negotiate meaning frequently. Another feature is an assessment section at the end of every unit, in which the main language points taught can be reviewed.

Prefaced by a "Welcome Unit,” Top Notch 1 has 128 pages and is divided into ten units with the following categories: vocabulary, conversation strategies, speaking, pronunciation, listening, reading, and writing. The units cover a broad range of topics, such as "getting acquainted” and "talking about transportation.” The language skills are not presented in the same sequence in every unit. To activate the learner's previous knowledge about the topic of the unit, a topic preview question is available. Its purpose is to introduce students to the content of the unit. Grammar, Conversation Strategies with Pair Work, Pronunciation, and Vocabulary are followed by Listening and Writing in most units. As previously mentioned, at the end of every unit, students can be assessed in a section called Checkpoint. Through integrated exercises that review the language taught in that unit, learners can evaluate their readiness for listening comprehension, grammar, and writing. The textbook also contains a section named Wrap-up, in which role plays 
are performed by the students in order to review the content of the unit. Finally, each unit ends with a section called Now I can, that is used to validate students' mastery of the unit's communication objectives. For supplementary material, Top Notch 1 offers an alphabetic word list, followed by a social language list, a pronunciation table, a list of non-countable nouns presented in the textbook, and a list of the irregular verbs.

The student textbook contains additional components such as a workbook, a class audio program, a DVD with a TV sitcom, interviews, and a CD-ROM, which also works as a CD player. The CD-ROM contains engaging activities such as an interactive workbook, games and puzzles, speaking practice, and even a karaoke section that enables students to sing pop songs while the lyrics are displayed on the screen. Also, the textbook offers a number of resources that benefit teachers: a teacher's edition book with lesson planners, a teacher's disk with printable activities, and a package of completed assessments that teachers can customize. In addition, a book called Copy \& Go provides busy teachers with interactive, ready-made activities as worksheets. For the institution, Top Notch 1 offers a placement test for all levels. Finally, the student textbook program contains an additional component called My English lab, an online learning tool developed to benefit students by providing a positive integration of the textbook with technology. My English $l a b$ is a website available once students purchase a code that enables them to personalize their English practice and assessment with activities that are graded automatically by a computer program.

\subsubsection{New Interchange}

The widely known series New Interchange currently in its second edition, incorporates a number of improvements suggested by both teachers and students from many countries around the world. Published in 2012 by Cambridge University Press, New Interchange was written by Jack C. Richards, Jonathan Hull, and Susan Proctor. It is the second textbook of a four-level series of 
textbooks designed for adult and young adult learners of ESL. The main focus of New Interchange is to teach English communicatively; therefore, listening and speaking skills are emphasized to increase learners' fluency and accuracy. The textbook was designed for beginners who aim to build a strong foundation to become proficient English speakers. It also offers learners grammar practice through authentic communication.

New Interchange is 105 pages long and does not follow the same organizational pattern in every unit. Here is the description of each section: Snapshot introduces relevant information retrieved from an authentic source such as magazines or newspapers; Conversation presents students with a new topic; Word Power enhances vocabulary and is either the first or the third section of the unit; Grammar Focus deals with grammar content in controlled and communicative activities; Pronunciation focuses on exercises that emphasize relevant features of spoken English; Listening displays different meaningful dialogues; Reading contains activities that include authentic sources; Writing suggests practical tasks; Activities and Fluency contains exercises that pair learners with classmates to further practice the teaching points of the unit; and Unit Summaries provides learners with a review of the most important grammar points presented in that unit.

The textbook is divided into sixteen units that include topics that are posed as questions: How do you spend your day?, How much is it? Do you like Jazz?, and How often do you exercise? Additional materials offered by New Interchange include a CD-ROM to be used in conjunction with the student's textbook, a workbook, audio CDs for the listening tracks of the textbook, and a video activity book. For teachers, there is a teacher's manual, a video teacher's guide, and a placement test. As a technological supplement, New Interchange offers an online website free of charge called Arcade, where students can use the Internet to review the content that was taught in class. Overall, New Interchange offers many supplemental resources prepared to help teachers. 


\subsubsection{American Headway 1}

Written by Liz and John Soars and published in 2009 by Oxford University Press, American Headway 1 is the first textbook in a six-level English course for adult and young adult learners. It offers high-quality graphic content. Unlike the two aforementioned textbooks, it focuses on reading and writing and includes longer reading texts and more writing activities. Many interactive resources are also offered by American Headway 1. Each of the twelve units is divided into two sections: Language Input, which includes language focus, vocabulary and pronunciation, and everyday English; and Language Skills Development, which is composed of integrated reading, listening, speaking, and writing.

The approach used to teach grammar is inductive. Each unit of American Headway 1 begins with a grammar section called Grammar Spot to attract learners' attention, but the grammar points are not explicitly explained. Instead, grammatical explanations are given in a reference section at the end of the textbook called Grammar Reference. The next section is called Practice and provides a variety of exercises designed to strengthen the grammar points that were already taught. It features the four skills, and the tasks integrate them by combining, for instance, reading and listening. The reading texts in American Headway 1 are long, and the writing exercises always focus on grammar. The section Vocabulary and Pronunciation presents a list of the words covered in the unit. Finally, a section called Everyday English provides learners with authentic communicative exercises.

The consistent organization of this textbook benefits both teachers and learners since the topics are always displayed in the same order and can be found easily. In total, American Headway 1 has 138 pages and contains twelve units that cover topics like "the world of work" and "meeting people.” Besides the grammar reference section, the textbook also provides audio scripts, 
additional pair work activities, and word and verb lists; phonetic symbols of consonants and vowels are placed in the appendix.

Beside the textbook itself, American Headway 1 offers supplementary instructional resources like a workbook with a testing resource and an audio CD. For students, there is also an audio center that enables learners to download the audio files of the textbook. Finally, as a technological feature, American Headway 1 offers a multi-ROM that can be used on Android phones to select ROMs to run. These ROMs promote the interactive practice of grammar, writing, listening, and vocabulary. For teachers, the course components include the teacher's book, a test generator, a CD-ROM, class audio CDs, and the teacher resource center that gathers materials in an online library. These materials include presentations and assessment materials.

Table 1 (below) displays the main features of the three textbooks; the two plus symbols indicate that extra focus was placed in the given category.

\subsection{Analytical Procedure}

The three ESL textbooks selected for this study were analyzed unit by unit, in a systematic fashion, using an evaluative checklist. The decision to evaluate every unit of the textbooks was made to provide a more reliable analysis and to identify which textbook units need improvement and may benefit from the integration of technology.

Table1. Comparative table

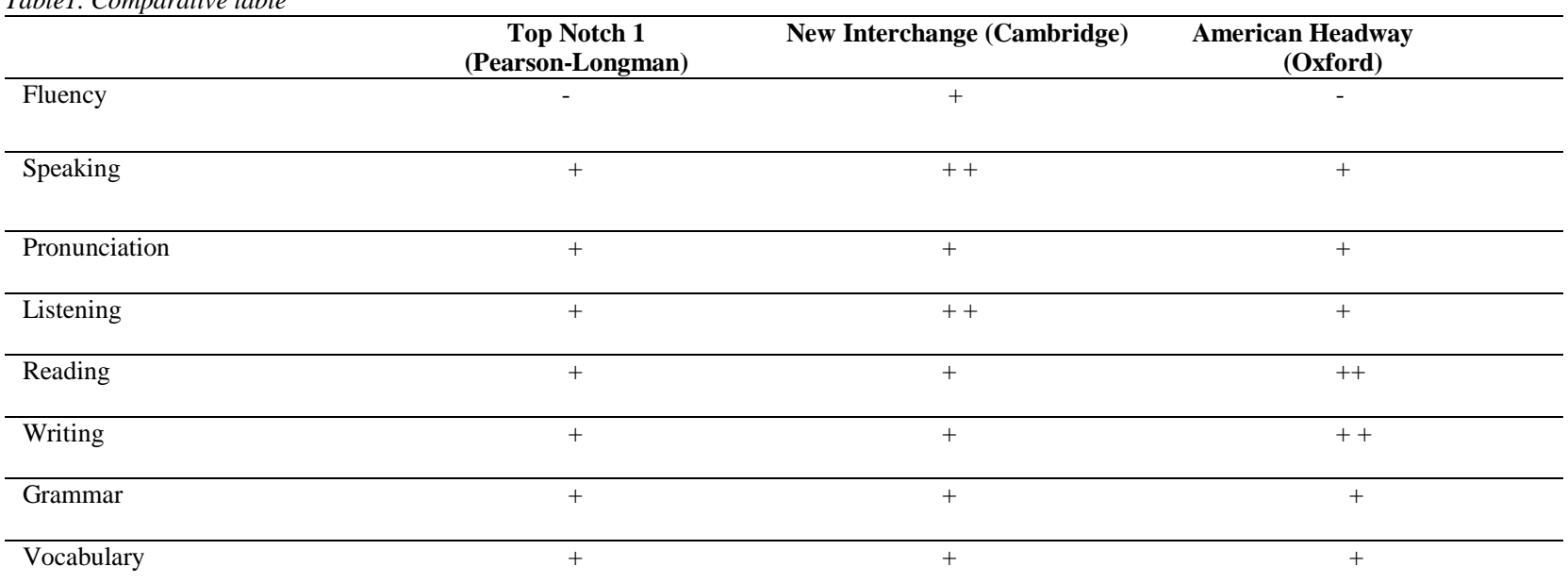


This table presents a summary of the textbooks' strong points and areas of weakness based on the application of a detailed evaluation checklist, which is described below. All the textbooks offered CD ROMs, glossaries, and online tools. American Headway 1 did not provide a review section and New interchange did not have any assessment and outcomes resources.

\subsubsection{Checklist Development}

In accordance with the review of the literature in Chapter 2, the following checklist was created (Table 2). Based on Byrd’s (2001), Skiersos’s (1991), and Shum and Glisan’s (2010) checklists, the checklist formulated for this study contains seven items related to the two research questions of this study. The seven items of the checklist were all adapted and simplified versions of their original items in the aforementioned studies. The decision to simplify the description was motivated by the fact that the original terms are probably easily comprehended by experienced educational professionals, but not by someone with less expertise (Mukundan \& Ahour, 2010). Tomlinson (2003) also suggests that shorter questions lead to clarity, thus making a checklist more useful. The checklist developed for this thesis avoided extensive questions that may lead to confusion, especially for novice teachers.

Table 2. Checklist

1. Contains written and spoken communicative tasks that provide students the opportunity to produce language.

2. Provides contextualized texts that lead students to use the target language communicatively.

3. Provides authentic materials (magazine articles, newspaper, etc.) and attractive graphic content (pictures or maps, etc.).

4. Includes preparatory pre-reading, pre-listening, and topic preview tasks.

5. Provides communicative practice whereby students must negotiate for meaning.

6. Integrates language skills (speaking, writing, reading, listening), grammar, and vocabulary.

7. Integrates technology and instruction (CD-ROM, World Wide Web, online chat rooms, etc.). 
The seven items of the checklist aim at answering the first research question of this study: "Do the selected textbooks provide culturally authentic and meaningful content and promote the development of communication skills through a variety of activities?” The second research question of this thesis, "What type of technology can be adopted to address weaknesses in the textbooks with regard to communicative activities? ” will be addressed in Chapter 4.

The first item of the checklist, "contains written and spoken communicative tasks that provide students the opportunity to produce language,” was based on Shrum and Glisan’s (2009) checklist item, which states "includes tasks in which students speak and write to an audience of listeners/readers.” Even though it is not explicitly stated in the item, writing assignments, answering questions, or performing a presentation individually are the activities to which this item refers. Jigsaw and information gap activities can also be present in the units of the textbooks that will be analyzed in this thesis.

As described earlier, Brazilian textbooks do not provide enough productive communicative student-centered tasks in their textbooks. For this reason, this item was included on the checklist. Waring (1997) argues that learners benefit from the practice of productive tasks because communication occurs when learners are speaking and writing in the second language. Therefore, textbooks must focus on speaking and writing activities that are well designed to expand student talk time in authentic real-life situations.

Similarly, the second item of the checklist was also concerned with the necessity for communicative tasks. The item, "provides contextualized texts that lead students to use the target language communicatively,” was based on two items of Shrum and Glisan (2005): “provides authentic printed texts that have engaging content and tasks” and "provides opportunities for students to select authentic texts to explore for enjoyment and learning.” The focus here is on competence and receptive skills, which consists of language that learners are able to understand 
(listening and reading) rather than produce (writing and speaking). The goal here is to explore texts and check how they lead students to communicate.

The third item of the checklist, "provides authentic materials (magazine articles, newspaper, etc.) and attractive graphic content (pictures or maps, etc.),” considers the attractiveness of the visuals of the textbook and the number of authentic sources that were cited. The selection of this item is justified by Skierso (1991), who claims that examining visual attributes of textbooks such as layout is mandatory for an effective evaluation. The presence of attractive visuals contributes to how students relate to the textbook, and it is crucial to assure students' interest in the material. Other researchers have also highlighted the importance of this aspect: Byrd (2001) and Skierso (1991) specifically examine "high aesthetic quality" of the pictures of the textbook. Shrum and Glisan (2010) included this question about visuals in order to assure that the textbook contains appealing aesthetic pictures to the students.

The next item on the checklist, “includes preparatory pre-reading, pre-listening, and topic preview tasks,” was partially taken from Shrum and Glisan’s (2010) checklist. Their original item was “includes pre-listening/ pre-viewing/ pre-reading tasks.” In this study I will be using the term “topic preview”, which consists of an introductory question followed by a discussion before the class begins exploring the section of the textbook. In addition to this unit-level preview activity, I will be looking at pre-reading and pre-listening activities tied to specific listening and reading within each unit.

There are many advantages to providing these three pre-activities to the students because they can establish the context to motivate students and activate their previous knowledge and vocabulary. Buck (2002) has emphasized that pre-listening activities can enhance learners’ confidence and can ease comprehensiveness because once the listener is familiar with the context, the chances of predictions and activation of previous schemata are higher. 
A topic preview consists of introducing material to students before they read a given unit of the textbook. The purpose of such action is to offer learners detailed information about the content of the unit of the book or about the text that will be read. For the analysis conducted in this thesis, topic preview is represented by some statements or rhetorical questions developed to raise students' interest and connect important points related to the topic to be discussed in that given section of the textbook. Such practice benefits students because it raises their attention about what they know about the topic that is being introduced. Then a short discussion question can be used to encourage students' involvement. Lazar (1993) defines previewing activities as mechanisms that can facilitate learner's comprehension of a textbook because it activates previous knowledge. In terms of previewing, to Swaffar et al. (1991), previewing activities enable learners to articulate hypotheses about the text they will see in the unit of the textbook.

Encouraging learners to be aware of the contextual clues such as titles, headlines, and pictures enables them to infer before reading. Chia (2001) also agrees that prereading activities are beneficial because learners can predict what the text is going to discuss, which, consequently, activates top-down processing. Through top-down processing, students activate background information to forecast what will be read or heard. The role of the teacher is imperative in the process of guiding learners to draw predictions, but even more important is that the textbook displays meaningful and noticeable pictures, illustrations, titles, and headlines.

In addition to predicting, Ringler and Weber (1984) affirm that the purpose of pre-reading activities is to motivate learners to read a text, provide meaningful background, and enable them to organize the activity and better understand the material that will be used. Chastain (1988) claims that pre-reading activities motivate and give learners a reason for reading a text. In addition, Grabe and Stroller (2002) believe that discussing the vocabulary that will be used in the text that will be read can result in an interesting pre-reading activity. 
The fifth item is "provides communicative practice whereby students must negotiate meaning.” According to Long (1981), negotiation of meaning entails repetition and occurs when learners rephrase and restructure what they are saying in order to communicate and/or comprehend the message accordingly. This item differs from the second item in the sense that for this item students have to communicate with each other and exchange information. Negotiation of meaning can be provided in textbooks through jigsaw readings and listening tasks that involve pairs or groups or activities that demand learners to share information toward a common goal. Whenever learners ask for clarification, negotiation of meaning occurs. Rephrasing and confirming information is also negotiation to assure that there was a clear comprehension of the message delivered by another person.

Sayer (2012) states that in jigsaw activities, students work in pairs or in small groups. Each person (or group) has different information. Jigsaw activities promote negotiation of meaning because both participants have to offer and receive information, which can occur through reading or listening. They also promote the integration of skills because learners can listen to and read a given text and speak to others in order to reaffirm the information that was presented. Such practice results in negotiation because the involved participants must both speak and understand the information accordingly to successfully complete the activity. Similarly, in information gap activities, students can also work in pairs or in groups and one of them contains information that the other one does not have (Sayer, 2012). The main difference between jigsaw and information gap activities is that the latter may result in less checking and feedback than the former. Consequently, information gap activities do not require closed answers, which is not the case with jigsaw activities, since each participant has the correct answer to the question that will be asked. Sayer (2012) explains that in information gap activities, student A observes the information about items that will be on sale during Black Friday at the local store. Student B uses his/her information 
to answer questions asked by student $\mathrm{A}$ in order to find out more about the items on sale. Note that there is no need of a specific, correct answer. Most of the time the flow of information tends to occur more in one side of the conversation, unless students exchange roles. Both students must participate. On the other hand, jigsaw activities are convergent, which means they only accept one correct answer. For example, students A and B are given a chart filled partially with information about three dogs, Sarge, Dixie, and Beargirl. The information might be about their age, their favorite food, and their favorite activities. Learners, then take turns, asking and answering questions without looking at each other's chart. They must ask for and provide missing information in order to complete the activity. Item number 5 was included in this thesis because Brazilian textbooks do not generally present meaningful communicative tasks. Thus, it is fundamental to analyze how these types of tasks are presented in the evaluated materials.

The sixth item, “integrates language skills (speaking, writing, reading, listening), grammar, and vocabulary,” combines the following items from Shrum and Glisan's checklist (2010, p. 65): “provides for integrated practice of the three modes of communication” and "presents clear, concise grammar explanations that are necessary for communication.” This item was included in the checklist because the integration of the skills can benefit learners when they are studying a second language. The many aspects of the different skills can help students’ comprehension, and combining productive and receptive skills is effective because in real-life situations, this integration occurs very frequently. Mohr and Mohr (2007) also support skill integration and indicate that language reception and production cannot be separated. The promotion of communicative language is sought in EFL textbooks in Brazil, and the use of integrated skills is believed to benefit learners because it promotes interaction and strengthens the learning process. Oxford (1989) suggests that integrated-skill textbooks enable teachers to monitor students’ progress in numerous skills at the same time. Additionally, the author indicates that this 
integration also encourages students to learn the real content, instead of the dissection of a fraction of language forms. As a consequence, Oxford (1989) advocates that content-based and task-based instruction present in an integrated-skill approach can greatly motivate students regardless of their age and levels.

The last item of the checklist is tied to the necessity of integrating technology in-EFL instruction. Adapted from Shrum and Glisan’s checklist (2010, p. 65), the item “integrates technology and instruction (CD-ROM, World Wide Web, online chat rooms, etc.)” was adopted and selected because it is pivotal to find out to what extent the evaluated textbooks incorporate technology given the increasing use of technological devices nowadays. Once the analysis is conducted, Chapter 4 will deal with the inadequacies discovered in the textbooks in order to determine how technology can be adopted to overcome these deficiencies. Finally, the aforementioned questions will be analyzed, and a discussion about the best textbook for communicative language teaching will be identified. In addition, the use of and relevance of technology in the classroom will be highlighted.

\subsubsection{Scoring Procedure and Rubric}

The scoring procedure was as follows. Each textbook unit was given a score of 1 (poor), 2 (satisfactory), or 3 (excellent) for each item on the checklist. Any mean score below 2 is considered problematic. The unit scores for each checklist item are then averaged to obtain the mean score for the textbook (see Tables 4, 5, and 6 below). To make the scoring process more efficient, an evaluative rubric was developed (Table 3) because a rubric is a tool that clearly displays the specifications for a given task and provides concise descriptions of the criteria needed to select a particular score. Rubrics are useful because they help the evaluator save time grading and be more aware of the grading process (Stevens \& Levi, 2011). 


\begin{tabular}{|c|c|c|c|}
\hline & $\begin{array}{c}3 \\
\text { Excellent } \\
\end{array}$ & $\begin{array}{r}2 \\
\text { Satisfactory } \\
\end{array}$ & \begin{tabular}{|c|}
1 \\
Poor \\
\end{tabular} \\
\hline $\begin{array}{l}\text { 1. Contains written } \\
\text { and spoken } \\
\text { communicative } \\
\text { tasks that provide } \\
\text { students the } \\
\text { opportunity to } \\
\text { produce language }\end{array}$ & $\begin{array}{l}\text { The unit contains } \\
\text { more than five } \\
\text { communicative } \\
\text { productive student- } \\
\text { focused tasks. The } \\
\text { written and spoken } \\
\text { activities can include } \\
\text { jigsaw tasks and } \\
\text { information gap } \\
\text { tasks. Writing } \\
\text { assignments are } \\
\text { offered. The target } \\
\text { audience for } \\
\text { activities is } \\
\text { specified. }\end{array}$ & $\begin{array}{l}\text { The unit contains } \\
\text { from three to five } \\
\text { communicative } \\
\text { productive student- } \\
\text { focused tasks. The } \\
\text { written and spoken } \\
\text { activities can include } \\
\text { jigsaw tasks and } \\
\text { information gap tasks. } \\
\text { Writing assignments } \\
\text { are scarcely offered. } \\
\text { The target audience } \\
\text { for the activities is not } \\
\text { always specified. }\end{array}$ & $\begin{array}{l}\text { The unit contains up } \\
\text { to three } \\
\text { communicative } \\
\text { productive student- } \\
\text { focused tasks. The } \\
\text { written and spoken } \\
\text { activities can include } \\
\text { jigsaw tasks and } \\
\text { information gap tasks. } \\
\text { Writing assignments } \\
\text { are not offered. The } \\
\text { target audience for the } \\
\text { activities is not } \\
\text { specified. }\end{array}$ \\
\hline $\begin{array}{l}\text { 2. Provides } \\
\text { contextualized texts } \\
\text { that lead students to } \\
\text { use the target } \\
\text { language } \\
\text { communicatively. }\end{array}$ & $\begin{array}{l}\text { The unit contains } \\
\text { meaningful texts that } \\
\text { are integrated with } \\
\text { communicative } \\
\text { activities that lead } \\
\text { students to } \\
\text { communicate. Role } \\
\text { plays, dialogue, and } \\
\text { discussions are } \\
\text { included. }\end{array}$ & $\begin{array}{l}\text { The unit contains } \\
\text { meaningful texts that } \\
\text { do not necessarily } \\
\text { lead students to } \\
\text { communicate. Role } \\
\text { plays, dialogue, and } \\
\text { discussions are not } \\
\text { always included. }\end{array}$ & $\begin{array}{l}\text { The unit does not } \\
\text { contain meaningful } \\
\text { texts or the } \\
\text { contextualization does } \\
\text { not lead students to } \\
\text { communicate. Role } \\
\text { plays, dialogue, and } \\
\text { discussions are not } \\
\text { included. }\end{array}$ \\
\hline $\begin{array}{l}\text { 3. Provides } \\
\text { authentic materials } \\
\text { (magazine articles, } \\
\text { newspaper, etc.) } \\
\text { and graphic content } \\
\text { (pictures or maps, } \\
\text { etc.). }\end{array}$ & $\begin{array}{l}\text { The unit presents } \\
\text { authentic material } \\
\text { taken from an } \\
\text { authentic source. } \\
\text { The visual aspect of } \\
\text { the pictures is } \\
\text { appealing and the } \\
\text { drawings are } \\
\text { updated. }\end{array}$ & $\begin{array}{l}\text { The unit does not } \\
\text { always present } \\
\text { authentic material } \\
\text { taken from an } \\
\text { authentic source, but } \\
\text { that is compensated } \\
\text { for by an appealing } \\
\text { visual aspect. }\end{array}$ & $\begin{array}{l}\text { The unit does not } \\
\text { present any authentic } \\
\text { material taken from an } \\
\text { authentic source, and } \\
\text { the visual aspect is not } \\
\text { appealing. }\end{array}$ \\
\hline
\end{tabular}


Table 3 (continued)

\begin{tabular}{|c|c|c|c|}
\hline $\begin{array}{l}\text { 4. Includes } \\
\text { preparatory pre- } \\
\text { reading, pre- } \\
\text { listening, and topic } \\
\text { preview tasks. }\end{array}$ & $\begin{array}{l}\text { All or most relevant } \\
\text { unit activities have a } \\
\text { pre-activity stage. }\end{array}$ & $\begin{array}{l}\text { Some relevant unit } \\
\text { activities have a pre- } \\
\text { activity stage. }\end{array}$ & $\begin{array}{l}\text { Few or no relevant } \\
\text { unit activities have a } \\
\text { pre-activity stage. }\end{array}$ \\
\hline $\begin{array}{l}\text { 5. Provides } \\
\text { communicative } \\
\text { practice whereby } \\
\text { students must } \\
\text { negotiate meaning. }\end{array}$ & $\begin{array}{l}\text { The unit contains at } \\
\text { least three } \\
\text { meaningful } \\
\text { communicative } \\
\text { activities that lead } \\
\text { learners to } \\
\text { communicate } \\
\text { purposefully. At } \\
\text { least three pair work, } \\
\text { role plays, } \\
\text { information gap, } \\
\text { jigsaw reading, and } \\
\text { listening tasks that } \\
\text { force negotiation of } \\
\text { meaning are } \\
\text { included. }\end{array}$ & $\begin{array}{l}\text { The unit contains at } \\
\text { least two meaningful } \\
\text { communicative } \\
\text { activities that lead } \\
\text { learners to } \\
\text { communicate } \\
\text { purposefully. } \\
\text { At least two pair } \\
\text { work, role plays, } \\
\text { information gap, } \\
\text { jigsaw reading, and } \\
\text { listening tasks that } \\
\text { force negotiation of } \\
\text { meaning are } \\
\text { included. }\end{array}$ & $\begin{array}{l}\text { The unit contains at } \\
\text { least one meaningful } \\
\text { communicative } \\
\text { activity that lead } \\
\text { learners to } \\
\text { communicate } \\
\text { purposefully. } \\
\text { Pair work, role plays, } \\
\text { information gap, } \\
\text { jigsaw reading, and } \\
\text { listening tasks that } \\
\text { force negotiation of } \\
\text { meaning are not } \\
\text { included. }\end{array}$ \\
\hline $\begin{array}{l}\text { 6. Integrates } \\
\text { language skills } \\
\text { (speaking, writing, } \\
\text { reading, listening), } \\
\text { grammar, and } \\
\text { vocabulary. }\end{array}$ & $\begin{array}{l}\text { All or most relevant } \\
\text { unit activities } \\
\text { integrate the } \\
\text { development of } \\
\text { speaking, writing, } \\
\text { reading, listening, } \\
\text { grammar, and } \\
\text { vocabulary. }\end{array}$ & $\begin{array}{l}\text { Some unit activities } \\
\text { integrate speaking, } \\
\text { writing, reading, } \\
\text { listening, grammar, } \\
\text { and vocabulary. }\end{array}$ & $\begin{array}{l}\text { Few or no unit } \\
\text { activities integrate } \\
\text { speaking, writing, } \\
\text { reading listening, } \\
\text { grammar, and } \\
\text { vocabulary. }\end{array}$ \\
\hline $\begin{array}{l}\text { 7. Integrates } \\
\text { technology and } \\
\text { instruction (CD- } \\
\text { ROM, World Wide } \\
\text { Web, online chat } \\
\text { rooms, etc.). }\end{array}$ & $\begin{array}{l}\text { The textbook } \\
\text { integrates } \\
\text { technology and } \\
\text { instruction that helps } \\
\text { students achieve the } \\
\text { task's objective with } \\
\text { meaningful activities } \\
\text { that benefit learners } \\
\text { considerably. }\end{array}$ & $\begin{array}{l}\text { The textbook } \\
\text { integrates technology } \\
\text { and instruction but the } \\
\text { technology does not } \\
\text { help students achieve } \\
\text { the task's objective. }\end{array}$ & $\begin{array}{l}\text { The textbook does not } \\
\text { integrate technology } \\
\text { and instruction. The } \\
\text { technology does not } \\
\text { help students achieve } \\
\text { the task's objective. }\end{array}$ \\
\hline
\end{tabular}




\subsubsection{Results and Discussion}

The results of the analysis of each textbook are given in Tables 4, 5, and 6 .

\section{Table 4. Scores for Top Notch 1}

\section{Checklist items}

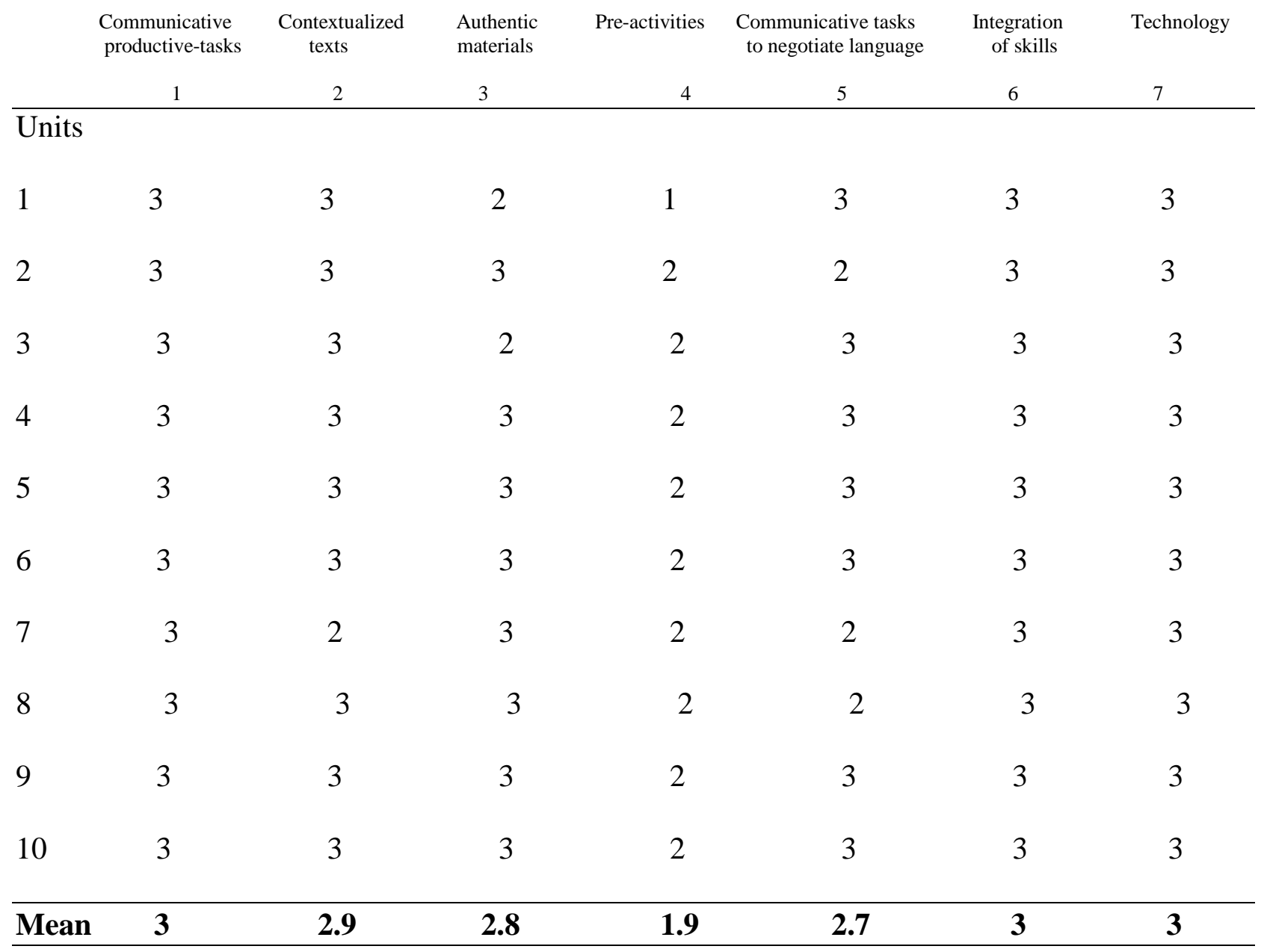

Grading scale: 1: Poor; 2: Satisfactory; 3: Excellent 


\section{Checklist items}

$\begin{aligned} & \text { Communicative } \\ & \text { productive-tasks }\end{aligned}$
$\begin{gathered}\text { Contextualized } \\ \text { texts }\end{gathered}$

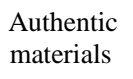

3
Pre-activities

2
Communicative tasks to negotiate language
Integration of skills

Technology

6

7

Units

\begin{tabular}{llllllll}
1 & 2 & 2 & 2 & 1 & 2 & 3 & 1 \\
2 & 2 & 2 & 3 & 2 & 2 & 3 & 1 \\
3 & 3 & 2 & 2 & 2 & 3 & 3 & 1 \\
4 & 2 & 2 & 2 & 2 & 2 & 3 & 1 \\
5 & 2 & 2 & 3 & 2 & 2 & 3 & 1 \\
6 & 2 & 2 & 2 & 2 & 2 & 3 & 1 \\
7 & 2 & 2 & 3 & 2 & 2 & 3 & 1 \\
8 & 2 & 2 & 3 & 2 & 2 & 3 & 1 \\
9 & 3 & 2 & 1 & 1 & 3 & 3 & 1 \\
10 & 2 & 2 & 2 & 2 & 2 & 3 & 1 \\
11 & 2 & 2 & 2 & 2 & 2 & 3 & 1 \\
12 & 3 & 2 & 2 & 2 & 3 & 3 & 1 \\
13 & 3 & 2 & 2 & 2 & 3 & 3 & 1 \\
14 & 2 & 2 & 2 & 2 & 2 & 3 & 1 \\
15 & 2 & 2 & 2 & 2 & 2 & 3 & 1 \\
16 & 2 & 2 & 1 & 2 & 2 & 3 & 1 \\
\hline Mean & $\mathbf{2 . 2}$ & $\mathbf{2}$ & $\mathbf{2 . 1}$ & $\mathbf{1 . 8}$ & $\mathbf{2 . 2}$ & $\mathbf{3}$ & $\mathbf{1}$ \\
\hline
\end{tabular}

Grading scale: 1: Poor; 2: Satisfactory; 3: Excellent 
Table 6. Scores for American Headway 1

Checklist items

$\begin{array}{cccccc}\begin{array}{c}\text { Communicative } \\ \text { productive-tasks }\end{array} & \begin{array}{c}\text { Contextualized } \\ \text { texts }\end{array} & \begin{array}{c}\text { Authentic } \\ \text { materials }\end{array} & \text { Pre-activities } & \begin{array}{c}\text { Communicative tasks } \\ \text { to negotiate language }\end{array} & \begin{array}{c}\text { Integration } \\ \text { of skills }\end{array} \\ 1 & 2 & 3 & 4 & 5 & 6\end{array}$

\begin{tabular}{|c|c|c|c|c|c|c|c|}
\hline \multicolumn{8}{|l|}{ Units } \\
\hline 1 & 1 & 2 & 2 & 1 & 1 & 3 & 1 \\
\hline 2 & 1 & 2 & 2 & 1 & 1 & 3 & 1 \\
\hline 3 & 1 & 2 & 2 & 1 & 1 & 3 & 1 \\
\hline 4 & 2 & 2 & 2 & 1 & 2 & 3 & 1 \\
\hline 5 & 2 & 2 & 2 & 1 & 2 & 3 & 1 \\
\hline 6 & 2 & 2 & 2 & 1 & 2 & 3 & 1 \\
\hline 7 & 1 & 2 & 2 & 1 & 1 & 3 & 1 \\
\hline 8 & 1 & 2 & 2 & 2 & 1 & 3 & 1 \\
\hline 9 & 2 & 2 & 2 & 1 & 2 & 3 & 1 \\
\hline 10 & 2 & 2 & 2 & 1 & 2 & 3 & 1 \\
\hline 11 & 1 & 2 & 2 & 1 & 1 & 3 & 1 \\
\hline 12 & 1 & 2 & 2 & 1 & 1 & 2 & 1 \\
\hline Mean & 1.4 & 2 & 2 & 1 & 1.4 & 3 & 1 \\
\hline
\end{tabular}

Grading scale: 1: Poor; 2: Satisfactory; 3: Excellent 
The results of the analysis show a great number of weaknesses in the textbooks. In total, four problematic areas are identified both in New Interchange and American Headway 1. The problematic items include: the low quality of the written and spoken tasks that provide students the chance to produce language (item 1 of the checklist); the need for more pre-listening, pre-reading activities, and topic preview activities (item 4); the lack of tasks that promote negotiation of meaning (item 5); and, finally, the deficiency in integrating technology in instruction (item 7). In total, only one weak area is observed in Top Notch 1: the lack of sufficient topic pre-viewing, prelistening, and pre-reading activities, which, coincidently, is the only problematic item found in all textbooks. Two units in New Interchange and four units of American Headway 1 had a mean score lower than 2. The problematic mean scores for Top Notch 1, New Interchange, and American

Headway 1 are given in Table 7 (see below).

Table 7. Comparative mean scores of problematic items evaluated

\begin{tabular}{|c|c|c|c|}
\hline $\begin{array}{l}\text { Problematic items } \\
\text { identified in the } \\
\text { analysis }\end{array}$ & $\begin{array}{l}\text { New } \\
\text { Interchange }\end{array}$ & $\begin{array}{l}\text { American } \\
\text { Headway } 1\end{array}$ & $\begin{array}{l}\text { Actual weaknesses } \\
\text { to be solved }\end{array}$ \\
\hline $\begin{array}{l}\text { 1. Contains written and } \\
\text { spoken communicative tasks } \\
\text { that provide students the } \\
\text { opportunity to produce } \\
\text { language. }\end{array}$ & & 1.4 & $\begin{array}{l}\text { The textbook offers both writing } \\
\text { and speaking tasks, but they did not } \\
\text { have communicative purpose. Lack } \\
\text { of audience was also another } \\
\text { problem. }\end{array}$ \\
\hline $\begin{array}{l}\text { 4. Includes preparatory pre- } \\
\text { reading, pre-listening, and } \\
\text { topic preview tasks. }\end{array}$ & 1.8 & 1 & $\begin{array}{l}\text { The textbook needs to add more pre- } \\
\text { activities. }\end{array}$ \\
\hline $\begin{array}{l}\text { 5. Provides communicative } \\
\text { practice whereby students } \\
\text { must negotiate meaning. }\end{array}$ & & 1.4 & $\begin{array}{l}\text { No information gap and jigsaw tasks } \\
\text { that forced negotiation of meaning } \\
\text { were included. The tasks were not } \\
\text { designed to produce negotiation of } \\
\text { meaning. }\end{array}$ \\
\hline $\begin{array}{l}\text { 7. Integrates technology and } \\
\text { instruction (CD-ROM, } \\
\text { World Wide Web, online chat } \\
\text { rooms, etc.). }\end{array}$ & 1 & 1 & $\begin{array}{l}\text { Lack of communicative purpose in } \\
\text { technological component. }\end{array}$ \\
\hline
\end{tabular}

According to Table 7, item number 1, which examines whether the written and spoken communicative tasks provide students the opportunity to produce language, American Headway 1 
had a mean score of 1.4. This textbook needs improvement in its tasks since many units scored 1 point. Even though the textbook offers both writing and speaking tasks, they did not have a communicative purpose. Lack of audience was also another problem. For example, a task simply asked students to "talk about where you live." No specific directions were stated, so the students are not going to use the information in any engaging manner. Page 5, exercise 7 has an example of a writing activity that did not specify the audience to which the students would produce their text. The exercise asked students to "write about you." Students do not even know if they have to produce a formal or informal text. These are all examples of activities that are not realistic or authentic. Students can communicate through much more meaningful and purposeful activities. The lack of purpose and context justifies the poor score attributed to these units.

Item 4 was particularly problematic: Most textbooks failed to include pre-reading, prelistening, and topic preview activities. Top Notch 1 scored 1.9; New Interchange, 1.8, and American Headway 1, 1.0. Only one pre-listening activity was presented by American Headway 1: Exercises 1 and 2 (p.74) asked students to list five things that make them happy and compare their list with a partner. Top Notch 1 always presented topic preview activities at the beginning of its units. The main topic of the unit 2 is “going out” (p. 16). The topic preview activity asks students to look at the newspaper entertainment page displayed in order to choose a concert to attend. Once the students have circled their favorite concert, they have to locate the venue on the map and let a partner know when and where the event will take place.

American Headway 1 presented a mean score of 1.4 for item 5. Only five units scored a satisfactory grade. The communicative productive tasks and the activities that demanded negotiation of meaning in American Headway 1 were considered satisfactory in Units 4, 5, 6, 9, and 10 with activities that may be conducive to negotiation of meaning. Unit 6 , graded satisfactorily according to the criteria determined in the rubric, includes a role play activity on 
page 44, in which each student works with a partner and pretends to be a journalist and a famous person. Another role play activity is offered on page 46 . Additionally, on page 43 another activity led learners to ask and answer meaningful questions about their daily routine. On the other hand, Unit 1 is not satisfactory because it did not offer role plays and the activities did not lead students to negotiate meaning. Exercise 1 on page 7, for instance, asks students to "say numbers 1-20 around the class.” There is no communicative purpose to perform such activity, nor did the remaining activities lead students to negotiate meaning.

Finally, the last weakness identified through the textbooks' analysis is related to the integration of technology, the seventh item of the checklist. Both New Interchange and American Headway 1 scored only 1 point in the final mean score for this item. Not surprisingly, since only one item was considered problematic in the textbook, Top Notch 1 scored excellent for all 10 units. The reason is that it included a technology-based resource called My English Lab that helps reinforce the corresponding content of the textbook. All of the tasks are intrinsically integrated into the content of the textbook. Top Notch 1, in conjunction with My English Lab, shows how the integration of technology can supplement meaningful activities that benefit learners considerably. For example, Unit 2 offers 11 additional exercises including a grammar and pronunciation coach which reviews the grammar points of the unit presented with the help of a video. There are also drag and drop exercises to help learners to unscramble sentences, additional reading and listening exercises, and even a recorder that enables students to record and compare their intonation in sentences related to the main topic of the unit. Students can compare their recordings with the pronunciation of a native speaker in order to check how their intonation is similar. Another example is found in Unit 7. It is an activity that asks learners to imagine they are traveling to a foreign country. Titled "Finding something to wear," learners had to justify their choices for clothes they would pack according to the climate and the culture of the country specified. The 
student was not provided a specific audience for this task. My English Lab, then, instructs learners to write a postcard to a friend describing their trip or a dream vacation. All the above examples clearly show how technologies like My English Lab can supplement textbook weakness and facilitate the development of varied teaching activities and tasks.

With a mean score of 1, neither New Interchange nor American Headway 1 presented technological resources that addressed communicative language learning. Even though New Interchange provides students a fun and free online website called Arcade with activities to practice, this tool was essentially a website with extra exercises that could as easily have been included in the students' textbooks. For example, Arcade promotes a fill-in-the-blank exercise with Wh-questions. This book could definitely include more meaningful activities that use the Internet to its best potential. The content of Arcade may not be as good as My English Lab, which presented more appropriate content, as mentioned above, because Arcade is free of charge and My English Lab costs \$45. Not surprisingly and probably for the same reason, American Headway 1 earned the mean score of 1 due to the poor quality of the activities presented in the Multi CDROM. Similar to the tasks presented by Arcade, the Multi CD-ROM basically consists of exercises that could be offered in class, like listening activities that only require students to click on the words they heard. The four problematic items mentioned above will be addressed in Chapter 4 with suggestions of technologies to remedy these weaknesses. 


\section{CHAPTER 4}

\section{SUGGESTIONS FOR IMPROVING WEAKNESSES IN TEXTBOOKS: TECHNOLOGY-BASED APPROACH}

This chapter suggests the use of technology in EFL instruction to address the weaknesses identified in the analysis of the textbooks described above. The chapter is divided into three subsections: 1) potential of technology to enhance textbooks’ weaknesses; 2) addressing the analyzed textbook shortcomings using the technology-based approach; and 3) technology-based communicative activities. This troubleshooting section is followed by concluding remarks about the study.

\subsection{The Potential of Technology to Enhance Textbooks' Weaknesses}

In Chapter 1, I discussed the lack of communicative textbooks in Brazil. Although the three textbooks selected for this study are considered better than the Brazilian ones, they still have a number of shortcomings. Most importantly, they fail to use modern technologies to enhance communicative language teaching and student learning. While some of the weaknesses identified in the textbooks can be addressed through the addition of communicative activities carried out in both traditional ways and non-traditional approaches that incorporate technology, the latter are often more effective because they motivate students by making the language learning fun. Furthermore, Prensky (2004) advocates that students will progressively request the integration of technology for educational purposes, and Rushby (2005) strongly advises educators to research the numerous pedagogical advantages of learning through technology.

Technology-based approaches are not only more dynamic and interesting; they also reflect current teaching practices and offer more up-to-date authentic materials from a constantly changing world. Textbooks are often outdated the moment they are released from the press and 
cannot be easily printed and distributed again. Printing is more time-consuming, costly, and involved than making changes through a dynamic, technology-based platform.

Teachers and students can benefit greatly from the use of technology when teachers are willing to learn the programs and implement their use in pedagogically sound ways. When technology is used purposefully, it is an important motivator and it can be an alternative for students who feel intimidated to interact with their peers in class. Even though most teachers are aware that technology is important to motivate language learning, computers and smartphones are rarely used in foreign language teaching in Brazil because they are seen as entertainment devices more than pedagogical tools. Additionally, financial and access-oriented issues certainly justify the scarce use of these technological devices in class. Research has shown, (Rueckert et al, 2013; Valk, Rashid, \& Elder,2010), however, that using smartphones, iPhones, iPads, and tablets in foreign language teaching increases students' access to effective online educational resources and provides a platform that students are more likely to use. It also offers innumerable research possibilities that may help users access different resources and save time, which is pivotal in the contemporary education setting.

Salaberry (2001) highlights that it is necessary to pay attention to the role that technology can play in language teaching, not because it is implied that technology "does things better," but because it is crucial to understand the relationships among language teaching, learning, and technology (p. 51). Combining technology and teaching practices in EFL classes can be welljustified, since it can bring a wide number of advantages to the students. Technology and instruction together can help learners improve word processing. As a consequence, learners are more engaged in the writing process which is important to productive tasks, as item number one of the checklist developed in this thesis described (especially when teachers decide to publish students' work) as acknowledged by Anderson and Speck (2001). Gorjian (2008) argues that the 
use of technology facilitates the learning process, and Cummins (2008) explains that one of its potentials is the manner in which the information is presented with graphics, sounds, text, and video. Leu and Leu (1997) claim that the Internet provides a great variety of electronic books that are enriched by technological features such as digitalized pronunciations that can attract learners' attention. Listening and speaking can also be considerably improved because learners can access a wide variety of videos and audios and engage in interpretive and interpersonal communication via Skype. Finally, Wang (2005) claims that the Internet provides so many accessible resources that it could now be considered a virtual library. The biggest advantage of such rich resources is that they are generally free of charge; one just needs to be connected to the Internet to access them.

Despite the omnipresence of the Web 2.0 and the great number of possibilities available to aid learners to improve their language skills, the successful integration of technology remains problematic in many contexts. The successful implementation of technology and instruction in EFL classes depends on the resources that are available in the environment where learning takes place. The ability of the teacher to integrate technology and instruction meaningfully also plays an important role. There are advantages and disadvantages for teachers who decide to integrate technology in ELT; ultimately, however, it is clear that the integration of technology in instruction requires extra attention from teachers. For this reason, Bax (2003) claims that teachers who decide to implement technology in instruction have to do it purposefully. Research suggests that educational websites and applications, when used in meaningful ways, can strengthen students’ foreign language abilities and reinforce foreign language acquisition by increasing their motivation. Technology also provides opportunities for perception and the use of language in an authentic way, which contributes to the collaborative learning process and provides students with a means of independently working on language development outside of the classroom.

\subsection{Addressing Textbook Shortcomings Using Technology}


The analysis of the three textbooks in this study revealed that all had some shortcomings in terms of activities. The purpose of this chapter is to address the textbooks' weaknesses through the integration of technology . The problematic areas identified were: 1) an insufficient number of communicative tasks that provide students the opportunity to develop their productive skills; 2) a lack of preparatory pre-reading, pre-listening, and topic preview tasks; and 3) insufficient communicative practice through which students must negotiate meaning. Two of the textbooks were particularly problematic. The first, American Headway 1, exhibited weaknesses with regard to evaluation items 1 (communicative productive-tasks) and 5 (communicative tasks to negotiate language). New Interchange 1 presented problems regarding item 4 (regarding the inclusion, prereading, and pre-listening, and topic preview activities) and yielded a mean score of 1.8. This section suggests technologies for improving the textbooks under consideration. Three technologies are selected to directly address the problematic items of the textbooks: Powtoon, Wikispaces Classroom, and WhatsApp. Powtoon was developed in 2012, and is a cloud-based platform that enables users to create and distribute animated presentations through videos. According to the official website (www.powtoon.com), more than eight million people benefit from this dynamic business presentation tool. Powtoon provides a large variety of tools and enables users to both record speeches to narrate videos or use a voice-over speaker that narrates their presentation. A variety of character models, templates, and dynamic visual effects are available to make the presentation more appealing. The final video can be uploaded to YouTube. There is no charge for videos that are ninety minutes long or less.

Wikispaces Classroom is an easily manageable social platform designed to engage students in writing assignments. Wikispaces Classroom is a free educational platform that can easily display videos and features discussions that can be used as pre-reading, pre-listening, and topic preview activities. Students can practice authentic presentational writing by answering questions 
posed by the teacher and commented on by other students. Created in 2005, Wikispaces Classroom (www.wikispaces.com) is also very accessible to students; it can be used on tablets, computers, and smartphones. According to the official website, more than ten million people are currently registered in the platform. Sulisworo (2012), argues that the use of the platform enables teachers to monitor learners’ progress and provide faster feedback. Teachers appreciate the fact that Wikispaces Classroom is practical and does not demand several drafts of the activity, given that comments can be placed in the platform very easily. Additionally, Wikispaces Classroom is an efficient tool to help teachers with the organization of activities and with class management because it offers great resources such as an attendance sheet online and a space to make announcements, create assignments, and post relevant content.

WhatsApp is a cross-platform mobile messaging application that serves as an excellent platform for interpersonal communication by enabling its users to share messages, written and audio texts, images, and videos. It, too, can be easily accessed by learners as long as they have the Internet. The app can be downloaded only on smartphones, but users can also download the software program to their computers. According to the Statista (www.statista.com), a statistics portal website that provides meaningful information about important institutions and business organizations, there are currently more than one billion active users on WhatsApp. Certainly one of the reasons why WhatsApp is widely used around the world is that it offers a great alternative to SMS (Short Message Service) and is nearly completely free of any charges. In addition, users of WhatsApp can create groups and share unlimited information.

In the following discussion, I will show how teachers and students can use the above technologies to enhance language learning. In Table 8, I present the identified weakness of the textbooks, with examples taken from various chapters. I then make suggestions about how to improve the activities, first with an example for the traditional classroom, followed by a 
technology-based solution, in which students use a computer, tablet, or smartphone (see Table 8

below and on the next page).

The main argument for using technology is that it can improve student learning in ways

that are often more effective than a traditional approach, primarily because students are more

motivated by technology.

In addition, technology can support the objectives of communicative language teaching by

promoting activities that involve real communication. Through the technologies described above,

students have opportunities to engage in authentic communication and focus on the technologies

that best fit their learning styles. According to Nunan (1989), different learners have different

needs, preferences, and cognitive styles. The teacher can offer to students more options for

improving their learning by using the technologies at hand, with which their learners are already

familiar and often use on a daily basis.

Table 8. Enhancing the textbooks' items with traditional and technology based-approach

\begin{tabular}{|c|c|c|c|c|}
\hline $\begin{array}{l}\text { Problematic } \\
\text { item }\end{array}$ & $\begin{array}{l}\text { Original Task/activity } \\
\text { taken from the textbook }\end{array}$ & $\begin{array}{l}\text { Language } \\
\text { Skill }\end{array}$ & $\begin{array}{l}\text { Suggestion of } \\
\text { communicative } \\
\text { activity with } \\
\text { traditional } \\
\text { approach }\end{array}$ & $\begin{array}{l}\text { Suggestion of } \\
\text { communicative } \\
\text { activity with } \\
\text { technology-based } \\
\text { approach }\end{array}$ \\
\hline $\begin{array}{l}\text { Contains } \\
\text { communicative tasks } \\
\text { that provide students } \\
\text { the opportunity to } \\
\text { produce language. }\end{array}$ & $\begin{array}{l}\text { Students will be able to } \\
\text { talk about themselves } \\
\text { using the simple past. In } \\
\text { the original activity, } \\
\text { students are asked to } \\
\text { complete seven exercises } \\
\text { using “did, was, or were.” } \\
\text { Then they had to ask two } \\
\text { other students these } \\
\text { questions. For example: } \\
\text { Where were you born? } \\
\text { Where did you live when } \\
\text { you were a child? Did } \\
\text { you live in a house or an } \\
\text { apartment? (p.50) }\end{array}$ & $\begin{array}{l}\text { Writing and } \\
\text { speaking } \\
\text { Learners write and } \\
\text { speak in a } \\
\text { prepared way. } \\
\text { Examples: without } \\
\text { the use of } \\
\text { technological } \\
\text { devices, students } \\
\text { will develop a } \\
\text { dialogue in order } \\
\text { to perform a role } \\
\text { play activity. }\end{array}$ & $\begin{array}{l}\text { In a role-play activity } \\
\text { conducted in class, } \\
\text { students have to pretend } \\
\text { they are part of a TV } \\
\text { program. Working in } \\
\text { groups of three, one of } \\
\text { them will be the } \\
\text { television's program } \\
\text { host, one other will be } \\
\text { the interviewer, and the } \\
\text { remaining one will } \\
\text { pretend to be a celebrity } \\
\text { who is being } \\
\text { interviewed to talk } \\
\text { about the past. }\end{array}$ & $\begin{array}{l}\text { Students write a short } \\
\text { text with information } \\
\text { about their lives. Then } \\
\text { they create the } \\
\text { animation and record } \\
\text { their voices in the lab. } \\
\text { They also prepare closed } \\
\text { captions, which will be } \\
\text { displayed in their video. } \\
\text { The questions of the } \\
\text { textbook will be used as } \\
\text { their guideline. }\end{array}$ \\
\hline
\end{tabular}


Table 8 (continued)

\begin{tabular}{|c|c|c|c|c|}
\hline $\begin{array}{c}\text { Problematic } \\
\text { item }\end{array}$ & $\begin{array}{l}\text { Original Task/activity } \\
\text { taken from the } \\
\text { textbook }\end{array}$ & $\begin{array}{l}\text { Language } \\
\text { Skill }\end{array}$ & $\begin{array}{l}\text { Suggestion of } \\
\text { communicative } \\
\text { activity with } \\
\text { traditional } \\
\text { approach }\end{array}$ & $\begin{array}{l}\text { Suggestion of } \\
\text { communicative } \\
\text { activity with } \\
\text { technology-based } \\
\text { approach }\end{array}$ \\
\hline $\begin{array}{l}\text { Item } 4 \text { of the } \\
\text { checklist } \\
\text { Includes preparatory } \\
\text { pre-reading, pre- } \\
\text { listening, and topic } \\
\text { preview tasks. }\end{array}$ & $\begin{array}{l}\text { Students will be able to } \\
\text { predict how people } \\
\text { greet each other in five } \\
\text { different countries. The } \\
\text { only pre-reading item } \\
\text { available in New } \\
\text { Interchange was the } \\
\text { question: "How do you } \\
\text { think the people in these } \\
\text { countries greet each } \\
\text { other?" (page 7). }\end{array}$ & $\begin{array}{l}\text { Reading, writing, } \\
\text { and speaking. } \\
\text { Learners use the } \\
\text { selected skills in } \\
\text { order to discuss } \\
\text { the topic } \\
\text { Examples: } \\
\text { students are } \\
\text { separated into } \\
\text { five groups and } \\
\text { write a list of } \\
\text { predictions about } \\
\text { the text. }\end{array}$ & $\begin{array}{l}\text { The instructor } \\
\text { separates the students } \\
\text { in } 5 \text { groups that will } \\
\text { represent the countries } \\
\text { mentioned in the text. } \\
\text { Then the students will } \\
\text { be given a diagram in } \\
\text { which they will write } \\
\text { their predictions about } \\
\text { the text. Finally, } \\
\text { students compare their } \\
\text { ideas with members of } \\
\text { other groups and } \\
\text { discuss their answers. }\end{array}$ & $\begin{array}{l}\text { Recommended } \\
\text { technology: } \\
\text { Wikispaces } \\
\text { Topic preview: } \\
\text { Wikispaces displays a } \\
\text { short video with people } \\
\text { presenting themselves. } \\
\text { Subtitles are available. } \\
\text { Pre-reading: The } \\
\text { teacher posts extra } \\
\text { questions and a short } \\
\text { video with greeting } \\
\text { customs in the } \\
\text { countries cited in the } \\
\text { textbook. } \\
\text { Pre-listening: The } \\
\text { teacher posts questions } \\
\text { that can help learners } \\
\text { to predict the content } \\
\text { of the listening. }\end{array}$ \\
\hline $\begin{array}{l}\text { Item } 5 \text { of the } \\
\text { checklist } \\
\text { Provides } \\
\text { communicative } \\
\text { practice whereby } \\
\text { students must } \\
\text { negotiate for } \\
\text { meaning }\end{array}$ & $\begin{array}{l}\text { Students will be able to } \\
\text { read the menu of a } \\
\text { restaurant in New York. } \\
\text { They will be able to } \\
\text { match the food with } \\
\text { pictures and write the } \\
\text { prices they hear. } \\
\text { Students listen to the } \\
\text { prices of twelve } \\
\text { different items that can } \\
\text { be purchased. Then they } \\
\text { practice saying the } \\
\text { prices and match them } \\
\text { to their correspondent } \\
\text { picture (p. 14) }\end{array}$ & $\begin{array}{l}\text { Reading, } \\
\text { speaking and } \\
\text { listening in an } \\
\text { activity } \\
\text { conducted in a } \\
\text { jigsaw activity. }\end{array}$ & $\begin{array}{l}\text { The instructor } \\
\text { separates students in } \\
\text { pairs. Then half of the } \\
\text { students will be given } \\
\text { a paper with the prices } \\
\text { of the twelve items that } \\
\text { can be purchased in a } \\
\text { restaurant. They will } \\
\text { pretend to be the } \\
\text { customers while the } \\
\text { other half of the class } \\
\text { will act as the } \\
\text { restaurant's attendant. }\end{array}$ & $\begin{array}{l}\text { Recommended } \\
\text { technology: WhatsApp } \\
\text { The teacher gives the } \\
\text { students a grid with } \\
\text { twelve pictures of } \\
\text { food. In the column of } \\
\text { the price, half of the } \\
\text { students, who represent } \\
\text { group A, are given half } \\
\text { of the correct prices for } \\
\text { the items. The other } \\
\text { half of students, who } \\
\text { represent group B, } \\
\text { have relevant } \\
\text { information to perform } \\
\text { as the customers. In a } \\
\text { role play, students A } \\
\text { and B have to perform } \\
\text { a dialogue in which } \\
\text { they are in a take-out } \\
\text { bakery and negotiate } \\
\text { the prices for the } \\
\text { products they will } \\
\text { purchase. The } \\
\text { conversation is } \\
\text { recorded on WhatsApp. }\end{array}$ \\
\hline
\end{tabular}


Table 8 shows that even though communicative activities with the traditional approach can address textbook weaknesses, the use of technology enables teachers and students to explore the tasks from a different and more dynamic point of view. Technology is also great alternative for students who might be intimidated by face-to-face interaction (Inman \& Sewell, 2000). Through technology they can engage with others in a low-stress learning environment. Powtoon, for example, enables students to practice presentational speaking in dynamic ways because students record their voices and create a cartoon. Additionally, learners add closed captions that are displayed once their cartoon is uploaded and delivered. Through this activity, learners engage in presentational writing and speaking by creating a script and delivering it orally. For students who feel intimidated to talk in front of their peers, that is a good alternative. In addition to Powtoon, both Wikispaces Classroom and WhatsApp provide a platform for students to practice presentational writing. Students are able to post comments in a controlled and safe environment, and teachers can assess students' areas of need and provide individualized feedback in real-time communication.

In the following section, I suggest how the above technologies can be used to address specific shortcomings of the textbooks analyzed earlier in this study. By incorporating these technologies in classroom instruction, teachers can provide essential supplements to their classroom texts in addition to making their instruction more stimulating and motivating.

\subsection{Technology-Based Communicative Activities}

Table 9 (see below) presents technology-based activities designed to enhance students' communication skills. After the analysis of this thesis was conducted and in order to answer the second research question of this study, this overview of what the technologies have to offer for each item on the checklist intends to improve the activities in American Headway 1. This 
textbook presented four problematic areas (see table 7), New Interchange showed 2 weak areas, and Top Notch only had one area graded poorly. In the following table, I use Headway 1 as an example of how technologies can be integrated to support content in the textbook. These technologies and the accompanying strategies can be implemented in all three textbooks in similar ways.

Table 9. Activity bank

\section{Checklist Item Original activity Selected} (American Headway) technology

Students will be able to WhatsApp write a description of the place where they live. They have to tell a partner about their home (p. 96).

\begin{tabular}{|c|c|c|}
\hline $\begin{array}{l}\text { 1. Contains written and } \\
\text { spoken communicative } \\
\text { tasks that provide } \\
\text { students the opportunity } \\
\text { to produce language. }\end{array}$ & $\begin{array}{l}\text { Students will be able to } \\
\text { write a description of } \\
\text { the place where they } \\
\text { live. They have to tell a } \\
\text { partner about their } \\
\text { home (p. 96). }\end{array}$ & WhatsApp \\
\hline
\end{tabular}

\section{Implementation of the activity}

Students will be able to write a transcript describing their homes. They record their presentation while they actually present their houses. The video is shared in the WhatsApp group of the class. Students make comments on what they like best about the house.

\begin{tabular}{lll}
\hline $\begin{array}{l}\text { 2. Provides } \\
\text { contextualized texts that } \\
\text { lead students to use the } \\
\text { target language }\end{array}$ & $\begin{array}{l}\text { After reading a text } \\
\text { about the White House, } \\
\text { students will be able to } \\
\text { ask and answer }\end{array}$ & $\begin{array}{l}\text { Wikispaces } \\
\text { Classroom }\end{array}$ \\
& $\begin{array}{l}\text { questions about the } \\
\text { most famous address in } \\
\text { Washington, DC } \\
\text { (p. } 36) .\end{array}$
\end{tabular}

\begin{tabular}{|c|c|c|c|}
\hline $\begin{array}{l}\text { 3. Provides authentic } \\
\text { materials (magazine } \\
\text { articles, newspaper, } \\
\text { etc.) and attractive } \\
\text { graphic content } \\
\text { (pictures or maps, etc.) }\end{array}$ & $\begin{array}{l}\text { Students will be able to } \\
\text { fill out a hotel's } \\
\text { booking form based on } \\
\text { the information } \\
\text { displayed in an email } \\
\text { written by Peter West } \\
\text { (p. 100). }\end{array}$ & WhatsApp & $\begin{array}{l}\text { Students will be able to record a } \\
\text { conversation in which they actually } \\
\text { have to book a room at a hotel that } \\
\text { will be found online. The } \\
\text { conversation is shared in the } \\
\text { WhatsApp group of the class. }\end{array}$ \\
\hline $\begin{array}{l}\text { 4. Includes preparatory } \\
\text { pre-reading, pre- } \\
\text { listening, and topic } \\
\text { preview tasks. }\end{array}$ & $\begin{array}{l}\text { Students will be able to } \\
\text { read a text about } \\
\text { Seamus McSporran and } \\
\text { his daily routine in } \\
\text { Scotland (p. 20). No } \\
\text { pre-reading, listening, } \\
\text { or topic preview was } \\
\text { offered for this task. }\end{array}$ & WhatsApp & $\begin{array}{l}\text { In this pre-reading and listening } \\
\text { activity, students will be asked to } \\
\text { write their predictions in the } \\
\text { WhatsApp group of the class. By } \\
\text { writing their answers down, students } \\
\text { can activate their background } \\
\text { knowledge about their daily routines } \\
\text { and even recall meaningful } \\
\text { vocabulary before they read the text. }\end{array}$ \\
\hline
\end{tabular}


Table 9 (continued)

\begin{tabular}{|c|c|c|c|}
\hline $\begin{array}{l}\text { 5.Provides } \\
\text { communicative practice } \\
\text { whereby students must } \\
\text { negotiate for meaning. }\end{array}$ & $\begin{array}{l}\text { Students will be able to } \\
\text { ask and answer } \\
\text { questions about (p. 25) } \\
\text { Lisa Parson, whose life } \\
\text { was described in the } \\
\text { previous exercise. } \\
\text { Additionally, they talk } \\
\text { about their own routine. }\end{array}$ & WhatsApp & $\begin{array}{l}\text { Students will be assigned partners. } \\
\text { Student A must answer the questions } \\
\text { based on Lisa Parson's routine. } \\
\text { Student B will answer the questions } \\
\text { based on their own routine. A video } \\
\text { and pictures that exemplify their } \\
\text { answers must be submitted to the } \\
\text { WhatsApp group of the class. } \\
\text { Everybody must decide whose } \\
\text { routine is busier than Lisa Parson's. }\end{array}$ \\
\hline $\begin{array}{l}\text { 6. Integrates language } \\
\text { skills (speaking, } \\
\text { writing, reading, } \\
\text { listening), grammar, and } \\
\text { vocabulary }\end{array}$ & $\begin{array}{l}\text { Students will be able to } \\
\text { describe their perfect } \\
\text { vacation after listening } \\
\text { and reading about it in } \\
\text { their textbook. They } \\
\text { also have to write a } \\
\text { postcard to a friend (p. } \\
\text { 80). }\end{array}$ & $\begin{array}{l}\text { Wikispaces } \\
\text { Classroom }\end{array}$ & $\begin{array}{l}\text { Students will be able to work with a } \\
\text { partner to select the perfect vacation. } \\
\text { One of them will be the travel's agent } \\
\text { and the other one will be the } \\
\text { customer. Using Wikispaces } \\
\text { Classroom, videos and enticing texts } \\
\text { about good locations will be } \\
\text { displayed. The contact will be done } \\
\text { online with comments on the videos } \\
\text { and textbooks. The final meeting to } \\
\text { set up the details about the decision } \\
\text { on the customer about the selected } \\
\text { destination must be uploaded. }\end{array}$ \\
\hline
\end{tabular}

7. Integrates technology and instruction (CDROM, World Wide Web, online chat rooms, etc.).
Students will be able to check an online advertisement for a job. They will be able to help the main character write a letter to apply for the job (p. 97)
Wikispaces Classroom Students will be able to look for a job. They must use Wikispaces Classroom to post the advertisement of a job they will find online. Using the letter displayed on page 97, students write their own letter and also share it on Wikispaces Classroom. Students will be assigned a partner to perform a Role Play in which one student is the hiring manager and the other one applies for the job. They have a video interview to discuss the job advertisement and the applicant's letter. The video will be uploaded on Wikispaces Classroom. 
In general, I suggest that WhatsApp could be used to allow students to record videos and voice messages. Additionally, written comments can be added, which enables learners to focus on their written skills. Wikispaces and Powtoon also present the same advantages. All the activities mentioned above can easily be adjusted to other textbooks.

\subsection{Concluding Remarks}

The thesis has addressed concerns regarding the insufficient number of communicative textbooks used in private schools in Brazil. I evaluated three textbooks widely used in private language schools in Brazil (Top Notch 1, New Interchange, and American Headway 1) using a self-designed checklist. The main objective of the two research questions of the study was to evaluate the textbooks and to assess the extent to which they provide appropriate communicative tasks for learners.

The analysis revealed that the three textbooks evaluated showed significant shortcomings regarding communicative activities. New Interchange and American Headway 1 both lacked effective communicative activities, while Top Notch 1 was found to present more communicative activities. However, all of the units in all of the textbooks had an insufficient number of pre-reading, pre-listening, and topic preview tasks. It can be assumed that teachers should be trained to provide these activities; therefore, the teacher's edition textbook should contain these activities that were not included in the students' edition. To address these weaknesses, I recommended the use of three different technologies (Powtoon, Wikispaces Classroom, and WhatsApp) which enable teachers to vary tasks and activities and present them in a dynamic manner and thus supplement textbooks' weaknesses. The recommended technologies also benefit students. They will increase the degree of motivation and confidence and provide students with a non-threatening environment and meet their individual needs. This is in line 
with research on the use of technology and its positive aspects on student performance (Stockwell, 2008, 2013). For example, Turgut (2011) shows how the use of laptops in class enables teachers to present content through games, which leads to efficient language learning.

The scope of the study could have been broadened by including textbooks from other institutions. Three textbooks do not represent the teaching of EFL in Brazil. Regarding the recommended technologies, they were chosen mainly because they are free of charge. There are other kinds of technologies available that could be considered in this study, but they were not because of their high cost.

Further research should be conducted to compile more reliable information about the institutions and the textbooks they use. The availability and implementation of technology in these schools should also be investigated. These are all areas that should be explored in the future to provide more efficient ways of teaching. I have looked at only one component of the teaching transactions, the textbooks. It is also desirable to conduct more studies to investigate the opinion of students and teachers regarding the use of technologies. Finally, evaluations of the curricula are needed to provide more insights about EFL in Brazil and identify ways of improving instruction and teaching material.

This study has shown that no textbook is perfect, and ultimately it is up to the teacher to make up for the weaknesses of the materials they use. By implementing technology to make up for shortcomings in textbooks, teachers will not only be able to improve their instructional materials, they will also develop a competence in utilizing technology in multiple contexts. 


\section{References}

Al Jarf, R. (2004). The effects of web-based learning on struggling EFL college writers. Foreign Language Annals, 37(1), 49 - 57. doi:10.1111/j.1944-9720.2004.tb02172.x, http://dx.doi.org/ 10.1111/j.1944-9720.2004.tb02172.x

Anderson, R., \& Speck, B. (2001). Using technology in K-8 literacy classrooms. Upper Saddle River, N.J.: Prentice-Hall.

Ansary, H., \& Babaii, E. (2002). Universal characteristics of EFL/ESL textbooks: A step towards systematic textbook evaluation. The Internet TESL Journal, 8(2). Retrieved from http:/iteslj.org/Ansary-textbooks.

Bax, S. (2003). CALL—past, present and future. System, 31(1), 13-28.

Bennett, L. L., \& Berson, M. J. (2007). Digital age: Technology-based k-12 lesson plans for social studies. Silver Spring, MD: National Council for the Social Studies. 
Bohn, H. I. (2003). The educational role and status of English in Brazil. World Englishes, 22(2), 159172.

Breen, M., \& Candlin, C. N. (1987). Which materials?: A consumer’s and designer’s guide. In L. E. Sheldon (Ed.), ELT Textbooks and Materials: Problems in Evaluation and Development. ELT Documents 126, (13-28). London: MEP/ The British Council.

British Council. (2014). Learning English in Brazil 2014: Understanding the aims and expectations of the Brazilian emerging middle classes. Retrieved from https://www.britishcouncil.org.br/sites/default/files/learning_english_in_brazil.pdf.

Buck, G. (2001). Assessing listening. Cambridge: Cambridge University Press.

Byrd, P. (2001). Textbooks: Evaluation for selection and analysis for implementation. In M. CelceMurcia, Brinton, D. M., Marguerite, A. S., \& Bohlke, D. (Eds.), Teaching English as a second or foreign language (415-428). US: Heinle \& Heinle, Thomson Learning Inc.

Carrell, D. \& Korwitz, J. (1994). Using concentrating techniques to study gender stereotyping in ELT textbooks. In J. Sunderland (Ed.), Exploring gender: Questions and implications for English language education (31-44). London: Prentice Hall.

Chandran, S. (2003). Where are the ELT textbooks? In W.A. Renandya (Ed.), Anthology series 44: Methodology and material design in language teaching: Current perceptions and practice and their implications (161-169). Singapore: SEAMO.

Chen, P. C. (2004). EFL student learning style preferences and attitudes toward technology-integrated instruction (Doctoral dissertation). University of South Dakota, DAI-A 64/08, 2813. 
Chia, H. L. (2001). Reading activities for effective top-down processing. English Teaching Forum, 39(1), 22-25.

Coracini, M. J. F. R. (2011). Interpretação, autoria e legitimação do livro didático: Língua materna e língua estrangeira [Interpretation, authorship, and legimization of the mother tongue and foreign language textbook], 17-26. Campinas, SP Pontes.

Croop, F. (2008). Student perceptions related to mobile learning in higher education (Master's thesis). Retrieved from ProQuest Dissertations and Theses database. (UMI No. 3341141)

Cummins, J. (2008). Computer assisted text scaffolding for curriculum access and language learning/acquisition. Retrieved from http://iteachilearn.org/cummins/comptext.html.

Cunningsworth, A. (1995). Choosing your coursebook. Macmillan Heinemann.

Da Silva, J. M. (2012). Implicações culturais e didáticas do inglês como língua internacional: o livro didático (Unpublished master’s thesis). Universidade de São Paulo, São Paulo, Brazil.

De Mejia, A. (2002). Power, prestige and bilingualism: International perspectives on elite bilingual education. bilingual education and bilingualism. Multilingual Matters.

Ellis, R. (1997). The empirical evaluation of language teaching materials, ELT Journal, 51(1), 69-82.

Ellis, R. (2014). Principles of instructed second language learning. In M. Celce-Murcia, Brinton, D. M., Marguerite, A. S., \& Bohlke, D. (Eds.), Teaching English as a second or foreign language (31-45). US: Heinle \& Heinle, Thomson Learning Inc.

Freire, P. (2002). Pedagogy of autonomy. Knowledge required for educational practice (25th ed.). São Paulo, SP: Paz e Terra. 
Gorjian, B. (2008). Developing linguistic and cultural perspectives of English as a foreign language through email discussion. The Jalt Call Journal, 4(3), 3-14.

Ghorbani, L. (2009). An investigation of the manifestation of sexism in EFL textbooks. Retrieved fromhttp://www.eric.ed.gov/ERICWebPortal/search/detailmi.jsp?_nfpb=true\&_\&ERICExtSearch_ SearchValue_0=ED505434\&ERICExtSearch_SearchType_0=no\&ano=ED505434.

Grabe, W., \& Stoller, F. L. (2002). Teaching and researching reading. London: Pearson Education.

Guerrettaz, A. M., \& Johnston, B. (2013). Materials in the classroom ecology. Modern Language Journal, 97(3), 779 -796. Retrieved from http://dx.doi.org/10.1111/j.1540-4781. 2013.12027.x.

Inman, J. A., \& Sewell, D. N. (2000). Taking flight with OWLs: Examining electronic writing center work. Mahwah, N.J: L. Erlbaum Associates.

Johnson, R. K. (1989). The second language curriculum. Cambridge: Cambridge University Press.

Khodabakhshi, M. (2014). Choose a proper EFL textbook: Evaluation of “skyline” series. Procedia Social and Behavioral Sciences, 98, 959-967.

Kong, K. (2009). A comparison of the linguistic and interactional features of language learning websites and textbooks. Computer Assisted Language Learning, 22(1), 31-55.

Lee, R. N. F., \& Bathmaker, A. M. (2007). The use of English textbooks for teaching English to vocational students in Singapore secondary schools: A survey of teachers' beliefs. RELC Journal, 38(3), 350-374. 
Leffa, V. J. (1999). O ensino de línguas estrangeiras no contexto nacional. The teaching of foreign languages in the national context. Contexturas, 4, 13-24.

Leu, D. J., \& Leu, D. D. (1997). Teaching With the Internet: Lessons From the Classroom. Norwood, MA: Christopher-Gordon.

Littlejohn, A. (1998). The analysis of language teaching materials: Inside the Trojan Horse. In B. Tomlinson (Ed.), Materials development in language teaching (190-216). Cambridge: Cambridge University Press.

Nunan, D. (2001). Designing Tasks for the Communicative Classroom. Cambridge: CUP.

Nunan, D. (1991). Language teaching methodology. New York: Prentice Hall.

Number of monthly active WhatsApp users worldwide from April 2013 to February 2016 (in millions). (n.d.). Retrieved March 20, 2016, from http://www.statista.com/statistics/260819/number-ofmonthly-active-whatsapp-users/Number of monthly active WhatsApp users worldwide from April 2013 to February 2016 (in millions).

McDonough, J., \& Shaw, C. (1993). Materials and methods in ELT. Blackwell.

McGrath, I. (2006). Teachers and learners images for coursebooks. ELT Journal, 60, 171-180. Retrieved from http://dx.doi.org/10.1093/elt/cci104.

Mill, D. (2000). Web-based technology as a resource for form-focused language learning. TESOL Quarterly, 34(3), 603-616. 
Miccoli, L. (2008). Brazilian EFL Teachers Experiences in Public and Private Schools: different contexts but similar challenges. In Kalaj, P., Menezes, V., \& Barcelos A.M.F. (Eds.), Narratives of Learning and Teaching EFL (65-79). New York: Palgrave McMillan.

Mohr, K. A. J., \& Mohr, E. S. (2007). Extending English-language learners' classroom interactions using the Response Protocol. The Reading Teacher, 60(5), 440.

Mukundan, J., \& Ahour, T. (2010). A review of course book evaluation checklists across four decades (1970-2008). In Tomlinson, B., \& Masuhara, H. (Eds). Research for materials development in language learning - Evidence for best practice. London: Continuum International Publishing Group.

Oliveira, S. (2008). Texto visual, estereótipos de gênero e o livro didático de língua estrangeira [Visual text, gender stereotypes, and the foreign language textbook]. Trabalho Linguística Aplicada, 47(1), 91-117.

Oxford, R. L. (1989). Language learning strategies: What every teacher should know. New York: Newbury House Publisher.

Prensky, M. (2004). The emerging online life of the digital native. Retrieved August, 7, 2008.

Rahimpour, S. (2013). TEFL textbook evaluation. Proceedings from the Global Summit on Education. Kuala Lumpur, Malaysia. Retrieved from http://worldconferences.net/proceedings

Igse2013/papers gse2013/203\% 20Sepideh\% 20Rahimpour-2. pdf.

Rahimpour, M., \& Hashemi, R. (2011). Textbook selection and evaluation in EFL context. World Journal of Education, 1(2), 62-68. 
Riazi, A.M. (2003). What textbook evaluation schemes tell us? A study of the textbook evaluation schemes of three decades. In W.A. Renanda (Ed.). Methodology and materials design in language teaching (52-68). Singapore: SEAMEO Regional Center.

Richards, J. C. (1998). Beyond training. Cambridge: Cambridge University Press.

Richards, J. C. (2005). New Interchange. Cambridge: Cambridge University Press.

Richards, J., Bycina, D., \& Brioux Aldcorn, S. (1995). New person to person student book I. Oxford: Oxford University Press.

Richards, J., \& Mahoney, D. (1996). Teachers and textbooks: A survey of beliefs and practices. Perspectives: Working Papers, 8(1), 40-61.

Richards, J. C., \& R. Schmidt, 2002. Longman dictionary of language teaching and applied linguistics. 3rd ed. London: Longman.

Roberts, J. T. (1996). Demystifying materials evaluation. System, 24(3), 375-389.

Kim, D., Rueckert, D., Kim, D.-J., \& Seo, D. Students’ perceptions and experiences of mobile learning. Language Learning \& Technology, 17(3), 52-73. Retrieved from http://lt.msu.edu/issues/october2013/kimetal.pdf

Rushby, N. (2005) Editorial. British Journal of Educational Technology, 36(2), 135-136.

Santos, D. M. D. (1997). Learning English as a foreign language in Brazilian elementary schools: Textbooks and their lessons about the world and about learning (Master's thesis). University of Oklahoma. 
Santos, D. (2002). Learning English as a foreign language in Brazilian elementary schools: Textbooks and their lessons about the world and about learning. Paradigm, 2(5), 25-38.

Saslow, J. M., \& Ascher, A. (2006). Top notch 1: English for today's world. New York: Pearson Longman.

Sheldon, L. (1988). Evaluating ELT textbooks and materials. ELT Journal, 42(2), 21-37.

Shrum, J. L., \& Glisan, E. W. (2010). Teachers handbook: Contextualized language instruction. Boston: Heinle \& Heinle.

Skierso, A. (1991). Textbook Selection and Evaluation. In M. Celce-Murcia (ed.). Teaching English as a second or foreign language. Boston: Heinle and Heinle.

Soars, L., \& Soars, J. (2001). American headway 1. New York: Oxford University Press.

Stevens, D. D., \& Levi, A. J. (2011). Introduction to rubrics: An assessment tool to save grading time, convey effective feedback, and promote student learning. Stylus Publishing, LLC.

Stockwell, G. (2008). Investigating learner preparedness for and usage patterns of mobile learning. ReCALL, 20(3), 253-70.

Stockwell, G. (2013). Technology and motivation in English-language teaching and learning. In E. Ushioda (Ed.), International perspectives on motivation: Language learning and professional challenges (pp. 156-175). Basingstoke, UK: Palgrave Macmillan

Sulisworo, D. (2012). Designing the online collaborative learning using the Wikispaces. International Journal of Emerging Technology and Learning, 7(1), 58-61. 
Swales, J. (1980). ESP: The textbook problem. The ESP Journal, 1(1), 11-23.

Swaffar, J. K., Arens, K., \& Byrnes, H. (1991). Reading for meaning: An integrated approach to language learning. Pearson College Division.

Swain, M. (1985). Communicative competence: Some roles of comprehensible input and comprehensible output in its development. In S. Gass, \& C. Madden (Eds.), Input in second language acquisition (235-253). Rowley, MA: Newbury House.

Swain, M. (2005). The output hypothesis: Theory and research. In E. Hinkel (Ed.), Handbook of research in second language teaching and learning (471-483). Mahwah, NJ: Lawrence Erlbaum.

Swain, M., \& Lapkin, S. (1995). Problems in output and the cognitive processes they generate: A step towards second language learning. Applied Linguistics, 16, 371-391.

Swender, E., \& Duncan, G. (1998). ACTFL Performance Guidelines for K-12 Learners. Foreign Language Annals, 31(4), 479-491.

Tomlinson, B., \& Masuhara, H. (2010). Published research on materials development for language learning. In B. Tomlinson, \& H. Masuhara (Eds.). Research for materials development in language learning: Evidence for best practice (1-18). London \& New York: Continuum.

Turgut, G. (Oct. 2011). A case study on use of one-to-one laptops in English as second language classrooms, Turkish Online Journal of Qualitative Inquiry,3(4), 28-47 . Retrieved from http://www.eric.ed.gov/ERICWebPortal/detail?accno=ED537755.

Ur, P. (1996). A course in language teaching: Practice and theory. Cambridge: Cambridge University. 
Valk, J., Rashid, A.T., \& Elder L. (2010). Using mobile phones to improve educational outcomes: An analysis of evidence from Asia. International Review of Research in Open and Distance Learning, 11(1), 117-140. Retrieved from http://www.irrodl.org/index.php/irrodl/article/download/794/1507

Waring, R. (1997). A study of receptive and productive learning from word cards. Studies in Foreign Languages and Literature, 21(1), 94-114.

Wang, L. (2005). The Advantages of Using Technology in Second Language Education: Technology Integration in Foreign Language Teaching Demonstrates the Shift from a Behavioral to a Constructivist Learning Approach. The Journal, 32(10), 38.

WhatsApp. (n.d). Retrieved March 20, 2016, from https://www.whatsapp.com/.

Wikispaces. (n.d.). Retrieved March 20, 2016, from https://www.wikispaces.com/. 
